\title{
Chemical composition, optical properties, and oxidative potential of water- and methanol-soluble organic compounds emitted from the combustion of biomass materials and coal
}

\author{
Tao Cao ${ }^{1,2,3}$, Meiju Li ${ }^{1,2,3}$, Chunlin Zou ${ }^{1,2,3}$, Xingjun Fan ${ }^{4}$, Jianzhong Song ${ }^{1,2,5}$, Wanglu Jia ${ }^{1,2}$, Chiling Yu ${ }^{1,2}$, \\ Zhiqiang Yu ${ }^{1,2}$, and Ping'an Peng ${ }^{1,2,3,5}$ \\ ${ }^{1}$ State Key Laboratory of Organic Geochemistry and Guangdong Provincial Key Laboratory of Environmental Protection and \\ Resources Utilization, Guangzhou Institute of Geochemistry, Chinese Academy of Sciences, Guangzhou 510640, China \\ ${ }^{2}$ CAS Center for Excellence in Deep Earth Science, Guangzhou 510640, China \\ ${ }^{3}$ University of Chinese Academy of Sciences, Beijing 100049, China \\ ${ }^{4}$ College of Resource and Environment, Anhui Science and Technology University, Anhui 233100, China \\ ${ }^{5}$ Guangdong-Hong Kong-Macao Joint Laboratory for Environmental Pollution and Control, Guangzhou 510640, China
}

Correspondence: Jianzhong Song (songjzh@gig.ac.cn)

Received: 22 February 2021 - Discussion started: 23 February 2021

Revised: 9 July 2021 - Accepted: 18 July 2021 - Published: 6 September 2021

\begin{abstract}
Biomass burning (BB) and coal combustion (CC) are important sources of brown carbon $(\mathrm{BrC})$ in ambient aerosols. In this study, six biomass materials and five types of coal were combusted to generate fine smoke particles. The $\mathrm{BrC}$ fractions, including water-soluble organic carbon (WSOC), humic-like substance carbon (HULIS-C), and methanol-soluble organic carbon (MSOC), were subsequently fractionated, and their optical properties and chemical structures were then comprehensively investigated using UV-visible spectroscopy, proton nuclear magnetic resonance spectroscopy $\left({ }^{1} \mathrm{H}\right.$ NMR $)$, and fluorescence excitationemission matrix (EEM) spectroscopy combined with parallel factor (PARAFAC) analysis. In addition, the oxidative potential (OP) of $\mathrm{BB}$ and $\mathrm{CC} \mathrm{BrC}$ was measured with the dithiothreitol (DTT) method. The results showed that WSOC, HULIS-C, and MSOC accounted for 2.3\%-22\%, $0.5 \%-$ $10 \%$, and $6.4 \%-73 \%$ of the total mass of combustionderived smoke $\mathrm{PM}_{2.5}$, respectively, with MSOC extracting the highest concentrations of organic compounds. The MSOC fractions had the highest light absorption capacity (mass absorption efficiency at $365 \mathrm{~nm}\left(\mathrm{MAE}_{365}\right)$ : 1.0 $2.7 \mathrm{~m}^{2} / \mathrm{gC}$ ) for both $\mathrm{BB}$ and $\mathrm{CC}$ smoke, indicating that MSOC contained more of the strong light-absorbing components. Therefore, MSOC may represent the total $\mathrm{BrC}$ better than the water-soluble fractions. Some significant differences were observed between the $\mathrm{BrC}$ fractions emit-
\end{abstract}

ted from $\mathrm{BB}$ and $\mathrm{CC}$ with more water-soluble $\mathrm{BrC}$ fractions with higher $\mathrm{MAE}_{365}$ and lower absorption Ångström exponent values detected in smoke emitted from BB than from CC. EEM-PARAFAC identified four fluorophores: two protein-like, one humic-like, and one polyphenol-like fluorophores. The protein-like substances were the dominant components of WSOC (47\%-80\%), HULIS-C (44\%$87 \%)$, and MSOC $(42 \%-70 \%)$. The ${ }^{1} \mathrm{H}-\mathrm{NMR}$ results suggested that $\mathrm{BB} \mathrm{BrC}$ contained more oxygenated aliphatic functional groups $(\mathrm{H}-\mathrm{C}-\mathrm{O})$, whereas $\mathrm{CC} \mathrm{BrC}$ contained more unsaturated fractions $(\mathrm{H}-\mathrm{C}-\mathrm{C}=$ and $\mathrm{Ar}-\mathrm{H})$. The DTT assays indicated that $\mathrm{BB} \mathrm{BrC}$ generally had a stronger oxidative potential $\left(\mathrm{DTT}_{\mathrm{m}}, 2.6-85 \mathrm{pmol} / \mathrm{min} / \mu \mathrm{g}\right)$ than $\mathrm{CC} \mathrm{BrC}$ $\left(\mathrm{DTT}_{\mathrm{m}}, 0.4-11 \mathrm{pmol} / \mathrm{min} / \mu \mathrm{g}\right)$, with MSOC having a stronger OP than WSOC and HULIS-C. In addition, HULIS-C contributed more than half of the DTT activity of WSOC $(63.1 \% \pm 15.5 \%)$, highlighting that HULIS was a major contributor of reactive oxygen species (ROS) production in WSOC. Furthermore, the principal component analysis and Pearson correlation coefficients indicated that highly oxygenated humic-like fluorophore $\mathrm{C} 4$ may be the important DTT active substances in BrC. 


\section{Introduction}

Brown carbon $(\mathrm{BrC})$ is an organic compound with strong light absorption at ultraviolet and short visible wavelengths and is abundant in ambient aerosols (Chen and Bond, 2010; Laskin et al., 2015; Alexander et al., 2008), rain, clouds, and fog water (Santos et al., 2009, 2012; Izhar et al., 2020). Due to its strong light absorption ability, $\mathrm{BrC}$ can affect the radiative balance of aerosol and photochemical reactions in the atmospheric environment (Andreae and Gelencser, 2006; N. K. Kumar et al., 2018; Nozière et al., 2011). Moreover, $\mathrm{BrC}$ has the ability to catalyze the generation of reactive oxygen species (ROS), which potentially have an adverse impact on human health (Bates et al., 2019; Ma et al., 2018; Fan et al., 2018; Chen et al., 2019).

Brown carbon originates from various sources, including primary emission sources - such as biomass burning (BB), coal combustion (CC), and vehicular emissions (Fan et al., 2018; Li et al., 2018; Chen et al., 2019; Sun et al., 2017) - and secondary processes, such as reactions between carbonyls and ammonia or amines and the photochemical transformation of volatile organic compounds (Evangeliou et al., 2019; Lin et al., 2015). Among these sources, BB and CC are considered to make significant contributions to atmospheric $\mathrm{BrC}$ materials as indicated in both laboratory and field studies (Li et al., 2018; Park and Yu, 2016; van der Werf et al., 2010; Yan et al., 2015). For example, BrC fractions, such as water-soluble organic carbon (WSOC), humic-like substance carbon (HULIS-C), and methanol-soluble organic carbon (MSOC), have been found to be abundant in fresh emissions from the burning of crop straw, wood branches, and different coal types (Park and Yu, 2016; Fan et al., 2018; Li et al., 2018; Huo et al., 2018). These studies have also demonstrated that the chemical properties of primary $\mathrm{BrC}$ are variable due to the inherent heterogeneity and complexity of fuel materials and combustion conditions (Huo et al., 2018; Fan et al., 2018; Li et al., 2018; Atwi et al., 2021). For example, the light absorption properties of primary HULIS-C produced by the combustion of three types of crop straw under different moisture contents and stacking modes are different. The absorption Ångström exponent (AAE) increased and the mass absorption efficiency at $365 \mathrm{~nm}\left(\mathrm{MAE}_{365}\right)$ decreased under high moisture or stacking conditions (Huo et al., 2018). The water-soluble $\mathrm{BrC}$ emitted from low maturity $\mathrm{CC}$ generally had relatively low $\mathrm{MAE}_{365}$ values ( $\mathrm{Li}$ et al., 2018). However, most of these studies only focused on the relative abundances, chemical composition, and optical properties of water-soluble $\mathrm{BrC}$ (e.g., HULIS) emitted from the combustion of various fuels and different combustion conditions (e.g., smoldering and flaming) (Huo et al., 2018; Park et al., 2016; Fan et al., 2016). It is noted that water-insoluble $\mathrm{BrC}$ even exhibits a higher light absorption than water-soluble $\mathrm{BrC}$ in ambient aerosols (Chen et al., 2016, 2017; Bai et al., 2020; Huang et al., 2020; M. Li et al., 2019). However, knowledge on the chemical and optical properties of water-insoluble $\mathrm{BrC}$ from combustion sources is still lacking. Moreover, the association of chemical compositions responsible for light absorption of $\mathrm{BrC}$ from combustion sources is still constrained. Therefore, to gain more detailed information on $\mathrm{BrC}$ from combustion sources, a comprehensive characterization, including the chemical and optical characteristics of the $\mathrm{BrC}$ fractions (including both water-soluble and water-insoluble $\mathrm{BrC}$ ) from the combustion of biomass materials and coal, is required.

In addition, the oxidative potential (OP) data of watersoluble organic fractions (WSOC and HULIS) and the waterinsoluble organic fraction in ambient aerosols have been investigated, and all are known to be significant redox-active organic compounds associated with ROS generation, which can adversely affect human health (Moufarrej et al., 2020; Bates et al., 2019; Verma et al., 2012; Kramer et al., 2016; Wong et al., 2019). As important contributors to ambient $\mathrm{BrC}$, combustion-derived $\mathrm{BrC}$ is expected to have a strong ROS generation capacity and be harmful to human health. For example, the oxidative potential data of the water-soluble fraction of atmospheric fine aerosols were analyzed and revealed that biomass burning dominates the ROS-generation potential in winter, contributing more than $46 \%$ to dithiothreitol (DTT) activities in the southeastern United States (Verma et al., 2014) and $41 \%$ in Milan, Italy (Hakimzadeh et al., 2020). In addition, a study on the oxidative potential of water-soluble HULIS in fine aerosols in Beijing also indicated that combustion sources contributed a high proportion to the oxidative stress of water-soluble HULIS fractions (Ma et al., 2018). However, these results were mainly obtained based on the source apportionment receptor model (positive matrix factorization (PMF) and chemical mass balances (CMB)). Recently, the water extracts and HULIS from biomass burning were directly investigated and presented significant oxidative potential to generate ROS (e.g., $6.6-55 \mathrm{pmol} / \mathrm{min} / \mu \mathrm{g}$ for WSOC and HULIS extracted from biomass burning smoke) (Fan et al., 2018; Pietrogrande et al., 2021; Seo et al., 2020). In addition, high oxidative potentials $(2.04-15.5 \mathrm{pmol} / \mathrm{min} / \mu \mathrm{g})$ were also observed for water extracts in soot generated from the combustion of fossil fuels (R. Li et al., 2019; Zhu et al., 2019). However, these limited studies only focused on the water-soluble $\mathrm{BrC}$ fraction from biomass burning, and knowledge on the oxidative potential of the water-insoluble $\mathrm{BB} \mathrm{BrC}$ and $\mathrm{BrC}$ fractions emitted from other combustion processes, such as coal combustion, is still lacking. In addition, the DTT activities of BrC from different combustion sources were generally different, but the key components or functional groups that are responsible for the ROS generation capacity of combustion-derived $\mathrm{BrC}$ are unclear.

Biomass fuels and coal are two traditional sources of energy in residential properties in some developing countries, especially China and India (Sun et al., 2017; Huo et al., 2018; Singh et al., 2021). Due to incomplete combustion and poor pollution control, $\mathrm{BB}$ and $\mathrm{CC}$ release various 
pollutants, including particulate matter (PM), elemental carbon (EC), and BrC. In this study, we investigated the optical properties, chemical composition, and oxidative potential of $\mathrm{BrC}$ fractions in smoke types emitted from $\mathrm{BB}$ and CC. Six biomass materials (three types of crop straw and three types of wood branches) and five coal types with different maturities were combusted, and the resulting smoke particles were collected in a laboratory combustion chamber. The water-soluble (WSOC and HULIS-C) and methanolsoluble (MSOC) fractions in smoke were fractionated using pure water combined with solid-phase extraction (SPE) and methanol extraction. Subsequently, their chemical and optical properties were measured using a total organic carbon analyzer, UV-visible spectroscopy, fluorescence excitationemission matrix (EEM) spectroscopy combined with parallel factor (PARAFAC) analysis, as well as proton nuclear magnetic resonance spectroscopy $\left({ }^{1} \mathrm{H}\right.$ NMR). Moreover, the oxidative potential of the $\mathrm{BrC}$ fractions was determined by a DTT assay. This is a comprehensive study of the chemical and optical properties of $\mathrm{BrC}$ fractions, including both watersoluble and water-insoluble fractions from BB and CC. The OPs of different $\mathrm{BrC}$ fractions from $\mathrm{BB}$ and $\mathrm{CC}$ were directly determined, and the key components or properties associated with the OPs of $\mathrm{BrC}$ were further discussed. The information obtained will enhance our understanding of the chemical composition, light absorption, fluorophores, and DTT activity of the primary $\mathrm{BrC}$ from $\mathrm{BB}$ and $\mathrm{CC}$ and could be used to estimate the environmental and climate impacts of different types of combustion-derived $\mathrm{BrC}$.

\section{Materials and methods}

\subsection{The BB and CC smoke samples}

In this study, six biomass materials and five types of coal were collected and used to generate smoke samples. The biomass materials consisted of three types of crop straw (wheat straw (WS), rice straw (RS), and corn straw (CS)) and three types of wood branches (pine wood (PW), Chinese fir (CF), and white poplar (WP)). These materials are usually used as fuels for heating and cooking in rural areas and are also occasionally burned in the field (Fan et al., 2018; V. Kumar et al., 2018). The combustion of these crop straws and woody fuels is reported to make a significant contribution to atmospheric aerosols in China (Shen et al., 2013). Five types of coal were used for the collection of CC smoke samples. They consisted of four types of bituminous coal (B-1, B-2, B-3, and B-4) and one anthracite coal (AN), representing the major types of coal used for residential $\mathrm{CC}$ in China. The details of these samples are provided in the Supplement.

Samples of the smoke emitted from BB and CC were collected in a combustion and sampling system. The system consisted of a combustion hood, clean background air dilution and injection ports, smoke pipe, mixing fan, mixing chamber, $\mathrm{PM}_{2.5}$ sampler (JCH-120F, Juchuang Environmental Protection Group Co., Ltd., Shandong, China), and an exhaust port. The details of the sampling procedure are described in our previous study (Fan et al., 2018; Li et al., 2018) and the Supplement.

Blank quartz filters were collected before each group of combustion experiments prior to the fuels being ignited. Blank filters were used to correct the mass of smoke, the optical signals, and DTT consumption by BrC. To prevent contamination of the following sample, the collection system was cleaned before each new combustion experiment.

\subsection{Extraction and isolation of $\mathrm{BrC}$ fractions}

In this study, the WSOC, HULIS-C, and MSOC fractions were obtained using the solvent extraction method, as described in our previous studies (Fan et al., 2016; Li et al., 2018). Initially, the filter samples were cut into small pieces and ultrasonically extracted three times with $20 \mathrm{~mL}$ ultrapure water for $30 \mathrm{~min}$. The extract was filtered through a $0.22 \mu \mathrm{m}$ polytetrafluoroethylene (PTFE) syringe filter (Jinteng, Tianjin, China), which collected the WSOC fraction. The HULIS-C fraction in WSOC was further isolated using the SPE method (Oasis HLB, $200 \mathrm{mg}$, Waters, Milford, MA, USA). The detailed procedure is provided in Sect. S3 of the Supplement.

The MSOC fraction was obtained using a method developed by Cheng et al. (2016). Briefly, a portion of the filter was immersed in methanol (Macklin, > $99.9 \%$, Shanghai, China) for $2 \mathrm{~h}$ and then filtered through a $0.22 \mu \mathrm{m}$ PTFE syringe filter. Static digestion without ultrasonic treatment can avoid the loss of PM and facilitate the determination of the dissolved organic matter (DOM) content. Finally, the residual filters were dried in a vacuum dryer. The organic carbon (OC) content of MSOC was obtained by subtracting the OC concentration of the extracted filters from untreated filters.

\subsection{UV-visible spectroscopy}

The UV-visible (vis) absorption spectra of the $\mathrm{BrC}$ solutions were analyzed using a UV-vis spectrophotometer (UV-2600, Shimadzu, Kyoto, Japan). The BrC solution was placed in a $0.01 \mathrm{~m}$ quartz cuvette, and the UV-vis spectra were recorded from 200 to $700 \mathrm{~nm}$ at $1 \mathrm{~nm}$ intervals. Milli-Q water was used as a blank reference for the WSOC and HULIS-C solutions, while pure methanol was used as the blank for the MSOC fraction. The corresponding background was used to determine the interference from the instrument and operational blank sample.

To describe the optical properties of $\mathrm{BrC}$ fractions, the $\mathrm{AAE}$ and $\mathrm{MAE}_{365}$ were calculated in this study. The AAE is a measure of the spectral dependence of chromophores in $\mathrm{BrC}$, while the $\mathrm{MAE}_{365}$ can indicate the light-absorbing capacity of BrC (Fan et al., 2016; Cheng et al., 2016). The detailed calculations are described in the Supplement. 


\subsection{Fluorescence EEM spectroscopy and the PARAFAC model}

The EEM fluorescence spectra of $\mathrm{BrC}$ fractions were recorded by an F-4600 fluorescence spectrometer (Hitachi, Tokyo, Japan) using a $0.01 \mathrm{~m}$ width quartz cuvette with a $400 \mathrm{~V}$ xenon lamp at room temperature and a $2400 \mathrm{~nm} / \mathrm{min}$ scanning speed. The scanning ranges for excitation (Ex) and emission (Em) were 200-400 and 290-520 nm, respectively. The slit width and intervals for Ex and Em were both set to $5 \mathrm{~nm}$. According to the different solvents used for sample extraction (water and methanol), all EEM spectra were divided into two groups for analysis (66 samples for watersoluble WSOC and HULIS-C and 33 samples for MSOC). The PARAFAC modeling procedure was conducted in EFC $\mathrm{v} 1.2$, which is an application software based on MATLAB that has the functions of conversion, correction, cognition, comparison, and calculation for processing the fluorescence spectra (He and Hur, 2015; Murphy et al., 2011, 2013). The PARAFAC analysis method that was included in the software was consistent with the calculation made by the drEEM toolkit when using MATLAB (Murphy et al., 2010, 2013). The PARAFAC was computed using two to seven component models, with non-negativity constraints and a residual analysis, and split-half analysis was used to validate the number of fluorescence components. According to the results of the split-half and core consistency analysis, four component models were chosen for both the WSOC and HULIS-C fractions and the MSOC. The EEM was normalized to the area under the ultrapure water Raman peak $(E x=350 \mathrm{~nm}, \mathrm{Em}=365-430 \mathrm{~nm})$ collected before the measurement of samples to produce corrected fluorescence intensities in Raman units (Lawaetz and Stedmon, 2009). The relative contribution of individual chromophores was estimated by calculating the maximum fluorescence intensities $\left(F_{\max }\right.$ : maximum fluorescence intensity of identified fluorescence components, relative content $\%=F_{\max } / \Sigma F_{\max }$ ) (Matos et al., 2015; Chen et al., 2016).

\subsection{Proton NMR spectroscopy}

Approximately $5 \mathrm{mg}$ of the $\mathrm{BrC}$ fractions (i.e., HULIS-C, WSOC, and MSOC) derived from BB and CC were used for ${ }^{1} \mathrm{H}$-NMR measurements. The water-soluble $\mathrm{BrC}$ fractions (WSOC and HULIS-C) were redissolved in $500 \mu \mathrm{L}$ deuterium oxide, and MSOC was redissolved in $500 \mu \mathrm{L}$ deuterated methanol and then transferred to a $5 \mathrm{~mm}$ NMR tube. ${ }^{1} \mathrm{H}-$ NMR spectra were obtained at a frequency of $400 \mathrm{MHz}$ using a spectrometer (Avance III 400, Bruker Daltonik GmbH, Bremen, Germany). Data were acquired from 100 scans, with a recycling time of $2 \mathrm{~s}$ for a condensed water sample. The length of the proton $90^{\circ}$ pulse was $8.87 \mu \mathrm{s}$. A $1.0 \mathrm{~Hz}$ linebroadening weighting function and baseline correction were applied. The identification of the functional groups in the NMR spectra was based on their chemical shift $(\delta \mathrm{H})$ rela- tive to that of tetramethylsilane ( $0 \mathrm{ppm})$, which was applied as an internal standard (Zou et al., 2020).

\subsection{Oxidative potential}

The oxidative potential of $\mathrm{BrC}$ emitted from the $\mathrm{BB}$ and CC processes (i.e., WSOC, HULIS-C, and MSOC) was measured by a DTT assay. This protocol mainly followed the methods introduced by Fan et al. (2018) and Gao et al. (2020), with some minor modifications. Briefly, $3 \mathrm{~mL}$ of extracted sample solution (MSOC was a mixture of $100 \mu \mathrm{L}$ sample and $2.9 \mathrm{~mL}$ of $18.2 \mathrm{M} \Omega$ Milli-Q water, and the corresponding blank was the same solution as that of the water blank) and $3 \mathrm{~mL}$ of $1 \mathrm{mM}$ DTT were mixed in a $20 \mathrm{~mL}$ brown vial and then placed in a $37^{\circ} \mathrm{C}$ water bath to maintain the samples at a constant temperature. At specific time intervals $(0,5,10,15$, and $20 \mathrm{~min}), 1 \mathrm{~mL}$ of the well-mixed sample was transferred to another $4 \mathrm{~mL}$ brown vial, and $1 \mathrm{~mL}$ trichloroacetic acid (TCA $1 \% \mathrm{w} / \mathrm{v}$ ) was added to stop the

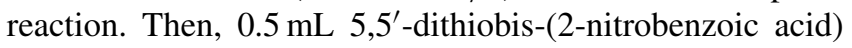
(DTNB, $1 \mathrm{mM}$ ) was added to react with the remaining DTT to produce 2-nitro-5-thiobenzoic acid (TNB). After $5 \mathrm{~min}$, $1 \mathrm{~mL}$ of tris(hydroxymethyl)methyl aminomethane buffer ( $0.4 \mathrm{mM}$ Tris buffer, $\mathrm{pH} 8.9$ in $4 \mathrm{mM}$ ) containing diethylene triamine pentaacetic acid (DTPA) was added, and the yellow color of TNB was visible in the mixed samples. The absorbance was measured at $412 \mathrm{~nm}$ with a UV-vis spectrometer (UV2600, Shimadzu). The DTT, TCA, and DTNB were all dissolved in $0.1 \mathrm{M}$ phosphate buffer $(\mathrm{pH}$ 7.4) containing $1 \mathrm{mM}$ DTPA, and the corresponding filter blank was analyzed to correct the DTT activity of the sample fractions. The DTT consumption rate after subtracting the field blank was determined using the absorbance and normalized by the particulate mass (DTT $\mathrm{m}, \mathrm{pmol} / \mathrm{min} / \mu \mathrm{g}$ ) (Verma et al., 2012; Fan et al., 2018). In this study, 1,4-phenanthraquinone was used to conduct a positive control, of which the DTT consumption rate was $0.46 \pm 0.03 \mu \mathrm{M}$ DTT/min $(n=10)$. The rate was similar to those reported in the previous studies (Fan et al., 2018; Lin and Yu, 2019).

Finally, principal component analysis (PCA) was performed to investigate the key factors that may affect the DTT activities from a series of characteristics of the $\mathrm{BrC}$ fraction. The details are described in Sect. S6 of the Supplement.

\section{Results and discussion}

\subsection{Abundance of WSOC, HULIS-C, and MSOC in BB and CC smoke samples}

Table 1 summarizes the abundance of $\mathrm{BrC}$ fractions, including WSOC, HULIS-C, and MSOC, in BB and CC smoke $\mathrm{PM}_{2.5}$ samples. As shown in Table 1, the average contribution of WSOC to smoke $\mathrm{PM}_{2.5}$ was $2.9 \%-12 \%$ and $2.3 \%$ $22 \%$ for BB and CC, respectively. These results were comparable to the results obtained for smoke samples from the com- 
Table 1. The contributions of BrC fraction (WSOC, HULIS, and MSOC) in smoke samples (\%).

\begin{tabular}{|c|c|c|c|c|c|c|c|c|c|c|c|}
\hline \multirow[b]{2}{*}{ Contents (\%) } & \multicolumn{6}{|c|}{ Biomass burning } & \multicolumn{5}{|c|}{ Coal combustion } \\
\hline & WS & RS & CS & PW & $\mathrm{CR}$ & WP & B-1 & B-2 & B-3 & B-4 & AN \\
\hline $\mathrm{OC}$ & $44 \pm 5.6$ & $41 \pm 12$ & $24 \pm 6.4$ & $19 \pm 3.8$ & $26 \pm 8.7$ & $23 \pm 13$ & $61 \pm 5.4$ & $64 \pm 11$ & $68 \pm 7.6$ & $69 \pm 6.9$ & $9.5 \pm 5.0$ \\
\hline EC & $2.5 \pm 0.9$ & $1.3 \pm 0.6$ & $4.4 \pm 2.8$ & $10 \pm 3.4$ & $5.0 \pm 3.3$ & $13 \pm 7.6$ & $0.2 \pm 0.1$ & $1.1 \pm 0.8$ & $0.3 \pm 0.1$ & $0.8 \pm 0.6$ & $0.1 \pm 0.0$ \\
\hline $\mathrm{TC}^{\mathrm{a}}$ & $46 \pm 5.5$ & $42 \pm 12$ & $28 \pm 8.2$ & $29 \pm 4.0$ & $32 \pm 9.6$ & $36 \pm 19$ & $61 \pm 5.4$ & $65 \pm 11$ & $69 \pm 6.7$ & $69 \pm 6.8$ & $9.5 \pm 5.0$ \\
\hline $\mathrm{WSOC} \mathrm{PM}^{\mathrm{b}}$ & $11 \pm 2.7$ & $12 \pm 1.6$ & $9.7 \pm 0.2$ & $3.9 \pm 1.1$ & $7.6 \pm 0.3$ & $2.9 \pm 0.7$ & $15 \pm 0.4$ & $22 \pm 4.1$ & $9.2 \pm 1.5$ & $4.7 \pm 0.4$ & $2.3 \pm 1.1$ \\
\hline HULIS-C/PM ${ }^{\mathrm{b}}$ & $6.7 \pm 1.3$ & $7.8 \pm 0.2$ & $4.0 \pm 0.5$ & $1.7 \pm 0.3$ & $3.1 \pm 0.6$ & $1.0 \pm 0.4$ & $6.0 \pm 0.6$ & $10 \pm 0.8$ & $4.2 \pm 0.4$ & $2.0 \pm 0.2$ & $0.5 \pm 0.1$ \\
\hline MSOC/PM ${ }^{\mathrm{b}}$ & $40 \pm 0.9$ & $47 \pm 0.8$ & $20 \pm 1.4$ & $12 \pm 1.2$ & $15 \pm 0.9$ & $6.4 \pm 0.7$ & $57 \pm 5.4$ & $73 \pm 2.9$ & $65 \pm 6.8$ & $71 \pm 0.7$ & $9.4 \pm 5.7$ \\
\hline WSOC/TC ${ }^{c}$ & $22 \pm 6.0$ & $23 \pm 3.0$ & $25 \pm 3.0$ & $14 \pm 3.1$ & $32 \pm 3.0$ & $21 \pm 9.4$ & $25 \pm 2.9$ & $29 \pm 4.3$ & $14 \pm 3.2$ & $6.4 \pm 0.5$ & $22 \pm 8.5$ \\
\hline HULIS-C/TC ${ }^{\mathrm{c}}$ & $14 \pm 2.8$ & $14 \pm 0.4$ & $11 \pm 2.7$ & $5.9 \pm 0.8$ & $13 \pm 1.6$ & $9.8 \pm 1.1$ & $10 \pm 0.3$ & $13 \pm 1.7$ & $6.3 \pm 0.9$ & $2.8 \pm 0.3$ & $6.9 \pm 2.9$ \\
\hline $\mathrm{MSOC} / \mathrm{TC}^{\mathrm{c}}$ & $82 \pm 2.2$ & $88 \pm 1.5$ & $57 \pm 11$ & $53 \pm 7.5$ & $78 \pm 16$ & $52 \pm 27$ & $99 \pm 0.2$ & $95 \pm 1.9$ & $98 \pm 0.1$ & $96 \pm 0.1$ & $95 \pm 1.8$ \\
\hline HULIS-C/WSOC ${ }^{\mathrm{c}}$ & $64 \pm 6.9$ & $65 \pm 8.0$ & $42 \pm 6.2$ & $43 \pm 5.4$ & $41 \pm 6.6$ & $32 \pm 6.3$ & $41 \pm 4.9$ & $46 \pm 9.4$ & $46 \pm 9.6$ & $43 \pm 6.0$ & $33 \pm 7.8$ \\
\hline WSOC/OC ${ }^{c}$ & $23 \pm 5.9$ & $23 \pm 3.1$ & $33 \pm 0.9$ & $24 \pm 4.0$ & $36 \pm 2.6$ & $35 \pm 3.2$ & $25 \pm 2.9$ & $30 \pm 4.5$ & $14 \pm 3.3$ & $6.4 \pm 0.5$ & $26 \pm 3.9$ \\
\hline HULIS-C/OC & $15 \pm 2.9$ & $15 \pm 0.4$ & $14 \pm 1.7$ & $10 \pm 0.7$ & $15 \pm 1.9$ & $11 \pm 3.2$ & $10 \pm 0.3$ & $13 \pm 1.6$ & $6.4 \pm 0.9$ & $2.8 \pm 0.3$ & $6.9 \pm 3.0$ \\
\hline $\mathrm{MSOC} / \mathrm{OC}^{\mathrm{c}}$ & $88 \pm 1.9$ & $91 \pm 1.2$ & $70 \pm 4.5$ & $76 \pm 2.5$ & $72 \pm 6.7$ & $77 \pm 4.5$ & $99 \pm 0.1$ & $96 \pm 0.5$ & $98 \pm 0.1$ & $98 \pm 0.5$ & $96 \pm 1.6$ \\
\hline
\end{tabular}

a Total carbon: sum of OC and EC. ${ }^{b}$ The ratios of the mass of carbon ( $\left.\mu \mathrm{gC}\right)$ to the mass of PM ( $\left.\mu \mathrm{g}\right)$ for each sample. ${ }^{\mathrm{c}}$ The ratios of the mass of carbon ( $\left.\mu \mathrm{gC}\right)$ to the mass of carbon ( $\left.\mu \mathrm{gC}\right)$ for each sample.

bustion of cherry leaves (16\%), gingko tree leaves $(6.0 \%)$ (Park et al., 2013), corn straw (5.9\%), pine branches (6.4\%) (Fan et al., 2016), and residential coal (4\%-11\%) (Li et al., 2018) and in the ambient $\mathrm{PM}_{2.5}$ from rural and urban sites (4\%-13\%) (Matos et al., 2015; Qin et al., 2018; Wu et al., 2020). This suggests that both BB and CC can release substantial amounts of water-soluble $\mathrm{BrC}$ into atmospheric aerosols. As the hydrophobic fraction of WSOC, the carbon content of HULIS (HULIS-C) accounted for $1.0 \%$ $7.8 \%$ and $0.5 \%-10 \%$ of $\mathrm{BB}$ and $\mathrm{CC}$ smoke $\mathrm{PM}_{2.5}$, respectively. These values are comparable to the results obtained for BB smoke (5.9\%-15.2\%) (Fan et al., 2018; Huo et al., 2018), CC smoke (1.9\%-4.8\%) (Li et al., 2018), and atmospheric aerosols in Beijing (4.8\%-9.4\%) (X. Li et al., 2019), with an average value of $7.2 \% \pm 3.3 \%$, therefore confirming the important contributions made by $\mathrm{BB}$ and $\mathrm{CC}$ to atmospheric HULIS. As a comparison, the contribution of MSOC to smoke $\mathrm{PM}_{2.5}$ was $6.4 \%-47 \%$ and $9.4 \%-73 \%$ for $\mathrm{BB}$ and $\mathrm{CC}$, respectively, with both values being much higher than the contributions of the water-soluble fractions (WSOC and HULIS-C) in the same smoke samples. Similar results have been reported in previous studies ( $\mathrm{Li}$ et al., 2018; Cheng et al., 2016), which suggest that there are more organic compounds that could be extracted by methanol than by water, and it could therefore be a better indicator of total $\mathrm{BrC}$. This result also indicated that $\mathrm{BB}$ and $\mathrm{CC}$ both released large amounts of water-insoluble $\mathrm{BrC}$ compounds, including hydrophobic polycyclic aromatic hydrocarbons (PAHs) and nitrogen/sulfur-containing heteroatomic PAHs (Geng et al., 2014; Dong et al., 2021; Huang et al., 2020).

Some differences were observed among the different types of smoke samples. As shown in Fig. 1, the average contributions of the WSOC and HULIS-C fractions to the total carbon (TC) were $22 \% \pm 7.3 \%$ and $11 \% \pm 3.8 \%$, respectively, for BB smoke, which were higher than the corresponding values of $19 \% \pm 9.4 \%$ and $8.2 \% \pm 4.0 \%$ for CC smoke. The contribution of MSOC to OC was $69 \% \pm 19 \%$ for BB,

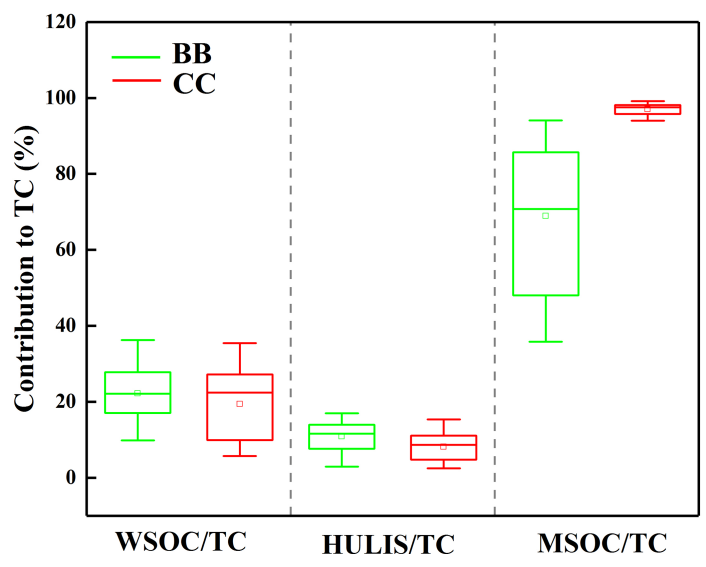

Figure 1. The abundances of $\mathrm{BrC}$ fraction in the smoke samples from biomass burning (BB) and coal combustion (CC).

which was significantly lower than the value of $97 \% \pm 1.8 \%$ for $\mathrm{CC}$. These results suggested that BB generally released the more water-soluble $\mathrm{OC}$ fraction, whereas more waterinsoluble OC fraction was contained in the smoke particles emitted from CC. These differences can be explained by the fact that biomass fuels generally contain large amounts of biopolymers, such as carbohydrates (cellulose, hemicellulose, etc.); the burning of biomass fuels produces more highly polar compounds, such as phenols, polyols, and polysaccharides; and CC emits more relatively hydrophobic and less polar components, such as coal tar and polycyclic aromatic species (Wu et al., 2014, 2021; Huang et al., 2020).

\subsection{Light absorption}

AAE and $\mathrm{MAE}_{365}$ are important optical indicators of the light absorption properties of atmospheric $\mathrm{BrC}$ and were investigated for $\mathrm{BB}$ - and $\mathrm{CC}$-derived $\mathrm{BrC}$ in this study. $\mathrm{As}$ shown in Fig. 2a and c, the AAE values of the WSOC and 

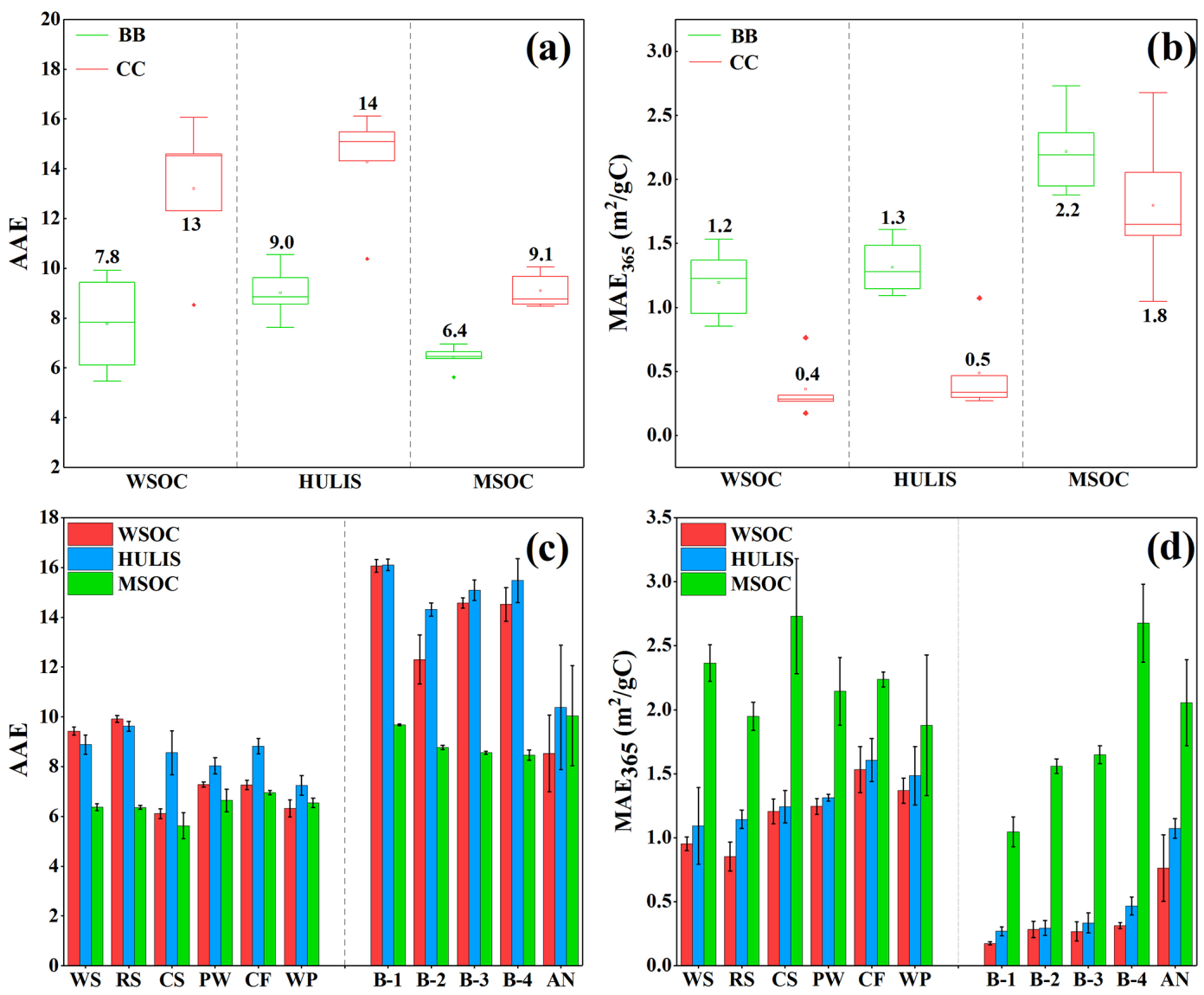

Figure 2. The AAE and $\mathrm{MAE}_{365}$ values of WSOC, HULIS, and MSOC in smoke samples from biomass burning (BB) and coal combustion (CC).

HULIS-C fractions were 6.1-9.9 (mean 7.8 \pm 1.6$)$ and 7.29.6 (mean $8.5 \pm 0.8$ ), respectively, for BB smoke and 8.516 (mean $13 \pm 2.9$ ) and $10-16$ (mean $14 \pm 2.3$ ), respectively, for CC smoke. These results were comparable to those measured for combustion-emitted aerosols with reported AAE values for HULIS of 7.4-8.3 (Park and Yu, 2016) and 6.28.1 (Fan et al., 2016, 2018) for BB smoke and 5.2-14 for CC smoke (M. Li et al., 2019). Moreover, the AAE values of BB WSOC and HULIS were also comparable to those reported for WSOC in urban aerosols in Beijing (mean $7.28 \pm 0.24$ ) (Cheng et al., 2016), HULIS in Amazon BB aerosols ( 7.10) (Hoffer et al., 2006), urban aerosols in Beijing (5.3-5.8) (Yan et al., 2015), and aerosols in the Tibetan Plateau (7.14-9.35) (Wu et al., 2020) but higher than that (1.2-5.4, mean of 3.2) of water-soluble BrC in Los Angeles (Zhang et al., 2013). However, the AAE values of the watersoluble $\mathrm{BrC}$ fraction from $\mathrm{CC}$ were almost higher than those in ambient aerosols, as described above. The AAE values for MSOC were 5.62-6.95 for BB smoke and 8.46-10.0 for CC smoke. It was obvious that the AAE value of BB MSOC was comparable to that of urban aerosols (average 7.10 \pm 0.45 ) in Beijing (Cheng et al., 2016) and the reported value (5.06.5) for urban aerosols in India (Mukherjee et al., 2020), but the AAE values of CC MSOC were likely higher than those for urban aerosols. It is obvious that CC-derived $\mathrm{BrC}$ fractions (WSOC, HULIS-C, and MSOC) generally have relatively higher AAE values than ambient $\mathrm{BrC}$, thereby suggesting that the contribution of CC may improve the AAE values of $\mathrm{BrC}$ in the atmosphere and should not be ignored.

As shown in Fig. 2a and c, the average AAE values of the WSOC, HULIS-C, and MSOC fractions in BB smoke were all lower than those for the same $\mathrm{BrC}$ fraction in $\mathrm{CC}$ smoke, indicating that $\mathrm{BB}$-derived $\mathrm{BrC}$ had a weaker wavelength dependence than $\mathrm{CC}$-derived $\mathrm{BrC}$. This finding agreed with the results reported in a previous study (Fan et al., 2016). The $\mathrm{AAE}$ values of the $\mathrm{BrC}$ fraction also varied according to the type of $\mathrm{BrC}$ fraction. HULIS-C had the highest AAE values, which were slightly higher than those for WSOC but much higher than those for MSOC (Fig. 2a and c), indicating that water-soluble $\mathrm{BrC}$ fractions had a greater wavelength dependency than the corresponding MSOC. This was similar to the results of previous studies that found higher AAE values for WSOC than MSOC in ambient aerosols (Cheng et al., 2016; Kim et al., 2016) and can be explained by the fact that the strongly light-absorbing organic molecules are gen- 
erally comprised of aromatic structures with a high degree of conjugation and low solubility in water.

$\mathrm{MAE}_{365}$ is an important parameter that characterizes the light absorption ability of atmospheric BrC. As shown in Fig. 2b and d, the $\mathrm{MAE}_{365}$ values of WSOC and HULIS-C were 0.9-1.5 (mean 1.2 \pm 0.3 ) and 1.1-1.6 (mean $1.3 \pm 0.2) \mathrm{m}^{2} / \mathrm{gC}$, respectively, for $\mathrm{BB}$ smoke and $0.2-0.8$ (mean $0.3 \pm 0.2$ ) and $0.3-1.1$ (mean $0.4 \pm 0.3$ ) $\mathrm{m}^{2} / \mathrm{gC}$, respectively, for $\mathrm{CC}$ smoke. As the hydrophobic fraction of WSOC, the $\mathrm{MAE}_{365}$ values of HULIS-C in BB and CC smoke were slightly higher than that of the corresponding WSOC, suggesting that HULIS-C had a stronger lightabsorbing ability. Moreover, the $\mathrm{MAE}_{365}$ values of WSOC and HULIS-C in BB smoke were comparable with the results of previous studies of the WSOC and HULIS-C fractions in combustion-released smoke particles and ambient aerosols. For example, the reported $\mathrm{MAE}_{365}$ values of WSOC and HULIS-C were $0.8-1.6$ and $1.0-1.5 \mathrm{~m}^{2} / \mathrm{gC}$, respectively, in $\mathrm{BB}$ smoke $\mathrm{PM}_{2.5}$ (Park and $\mathrm{Yu}, 2016$; Huo et al., 2018); 0.3-1.0 and 0.5-1.4 $\mathrm{m}^{2} / \mathrm{gC}$, respectively, in $\mathrm{CC}$ smoke particles (Li et al., 2018); and $0.1-1.5 \mathrm{~m}^{2} / \mathrm{gC}$ in ambient aerosols (Cheng et al., 2016; Yan et al., 2015; Zou et al., 2020). In contrast, the $\mathrm{MAE}_{365}$ values for MSOC were $1.9-2.7 \mathrm{~m}^{2} / \mathrm{gC}$ for $\mathrm{BB}$ smoke and $1.0-2.7 \mathrm{~m}^{2} / \mathrm{gC}$ for $\mathrm{CC}$ smoke, which were 1.3-8.5 times higher than the corresponding values for HULIS-C and WSOC and suggest that MSOC had the strongest light absorption capacity. The $\mathrm{MAE}_{365}$ values of $\mathrm{BB}$ and $\mathrm{CC}$ MSOC were comparable to the $\mathrm{MAE}_{365}$ values of urban aerosols in Beijing winter (average $1.45 \pm 0.26 \mathrm{~m}^{2} / \mathrm{gC}$ ) (Yan et al., 2015) and the water-insoluble $\mathrm{BrC}\left(0.85-2.45 \mathrm{~m}^{2} / \mathrm{gC}\right)$ in summer and winter ambient aerosols in Xi'an, northwest China (Li et al., 2020b). However, the values were higher than the $\mathrm{MAE}_{365}$ value of aerosol MSOC in the Central Tibetan Plateau (0.27$0.86 \mathrm{~m}^{2} / \mathrm{gC}$ ) (Wu et al., 2020), which may be due to the relatively low combustion source contribution in this region.

As shown in Fig. $2 b$ and d, some differences were observed among the BrC fractions. WSOC, HULIS-C, and MSOC in BB smoke all had relatively higher $\mathrm{MAE}_{365}$ values than the same $\mathrm{BrC}$ fractions from $\mathrm{CC}$, which suggested that $\mathrm{BrC}$ components emitted from $\mathrm{BB}$ had a relatively higher light absorption ability than those from $\mathrm{CC}$ and may therefore have a higher radiative force (Alexander et al., 2008). This finding is important for accurately assessing the climate effects of $\mathrm{BrC}$ from different combustion sources.

\subsection{Spectral EEM features and identification of PARAFAC components}

\subsubsection{The EEM fluorescence properties}

Fluorescence spectroscopy is a highly sensitive analytical technique for the identification of the sources and types of fluorophores in natural organic matter. In recent decades, fluorescence spectroscopy has been widely used to character- ize the fluorophores of atmospheric $\mathrm{BrC}$ in field and laboratory studies (Chen et al., 2017, 2016; Qin et al., 2018; Fan et al., 2020). The typical EEM spectra of WSOC, HULIS-C, and MSOC fractions from BB and CC are shown in Fig. S2. To avoid concentration effects, the fluorescence spectra were normalized by the OC content of WSOC, HULIS-C, and MSOC; and the specific fluorescence intensities (a.u. $\mathrm{L} /(\mathrm{gC})$ ) are shown.

In general, the different regions in the fluorescence spectra can be associated with organic fractions with different chemical characteristics (Table S1) (Chen et al., 2003; Cui et al., 2016; Qin et al., 2018). As shown in Fig. S2, the EEM spectra were divided into five regions: protein-like amino acid (I), protein-like UV region (II, peak $\mathrm{T}_{1}$ ), fulvic-like (III), tryptophan-like or microbial byproducts (IV, peak $\mathrm{T}_{2}$ ), and humic-like (V) fluorophores (Qin et al., 2018; Cui et al., 2016; Chen et al., 2016). It was observed that the WSOC and HULIS-C fractions exhibited two types of fluorescence peaks at $\lambda_{\mathrm{ex}} / \lambda_{\mathrm{em}} \approx(220-240) /(350-390) \mathrm{nm}$ (peak $\left.\mathrm{T}_{1}\right)$ and $\lambda_{\text {ex }} / \lambda_{\text {em }} \approx(260-300) /(240-380) \mathrm{nm}$ (peak $\mathrm{T}_{2}$ ) (as marked in Fig. S2), which were mainly located in regions II and IV, respectively. These bands in the same range as peaks $T_{1}$ and $\mathrm{T}_{2}$ have previously been identified in the EEM fluorescence spectra of water-soluble organic matter from rainwater/fog water (Santos et al., 2009, 2012) and $\mathrm{PM}_{2.5}$ in an industrial city in northwest China (Qin et al., 2018). As shown in Fig. S2, the fluorescence peaks $\mathrm{T}_{1}$ and/or $\mathrm{T}_{2}$ were the dominant peaks for WSOC and HULIS-C in BB- and CC-derived smoke samples, which were consistent with previous observations of the WSOC and HULIS-C fractions from BB (Huo et al., 2018; Fan et al., 2020). In general, peak $\mathrm{T}_{1}$ mainly corresponded to the protein-like $\mathrm{UV}$ region, with a minor contribution from fulvic-like substances, whereas peak $\mathrm{T}_{2}$ was assigned as tryptophan-like or microbial byproduct fluorophores. However, as reported in recent studies, non-nitrogen-containing species, such as naphthalene and phenol-derived compounds, may also contribute to the fluorophores with peak $\mathrm{T}_{2}$ in atmospheric aerosols (Chen et al., 2017, 2020). In addition, the intensity of peak $T_{1}$ for BB- and CC-derived HULIS-C fractions was clearly stronger than the peak in ambient HULIS described in previous studies (Chen et al., 2017, 2016; Fan et al., 2020; Qin et al., 2018), indicating that these BB- and CC-derived HULIS-C might consist of more protein-like and/or aromatic amino acids than atmospheric HULIS. However, these protein-like fluorescence peaks were observed to gradually decrease during the aging process (e.g., hydroxyl radicals or ozone oxidation) in previous studies (Fan et al., 2019, 2020). This implied that most protein-like fluorophores in $\mathrm{BB}$ or $\mathrm{CC} \mathrm{BrC}$ fractions may have high reactivity.

As shown in Fig. S2, the EEM spectra of the three MSOC fractions from crop straw burning all had a strong fluorescence peak at long emission wavelengths $(E x=205-280 \mathrm{~nm}$, $\mathrm{Em}=360-380 \mathrm{~nm}$ ), which were located in regions $\mathrm{V}$ and IV and were generally assigned to humic-like fluorophores (Qin 


\section{(a) WSOC and HULIS}

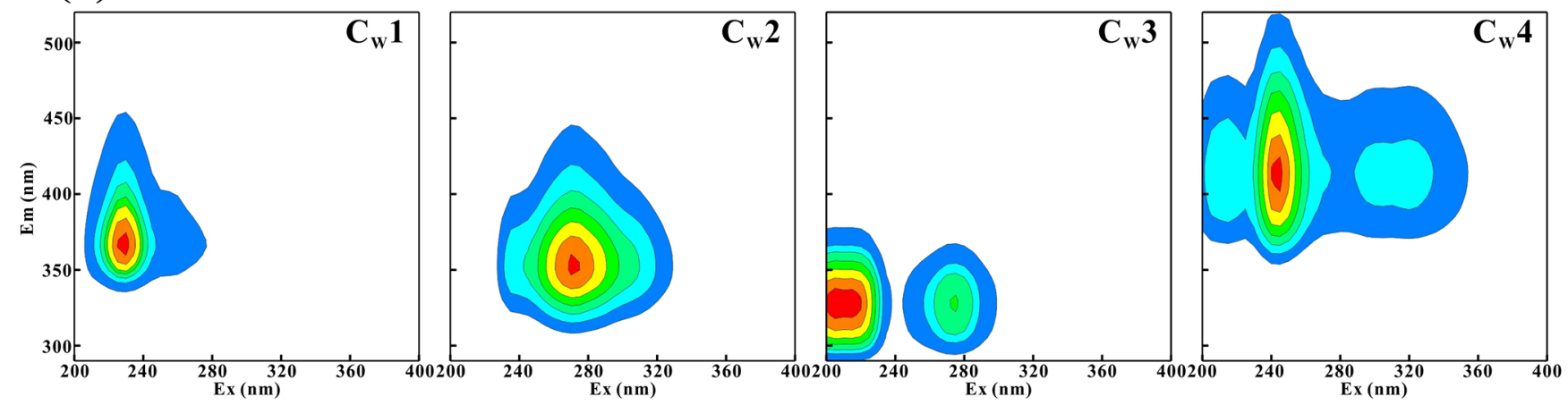

(b) MSOC

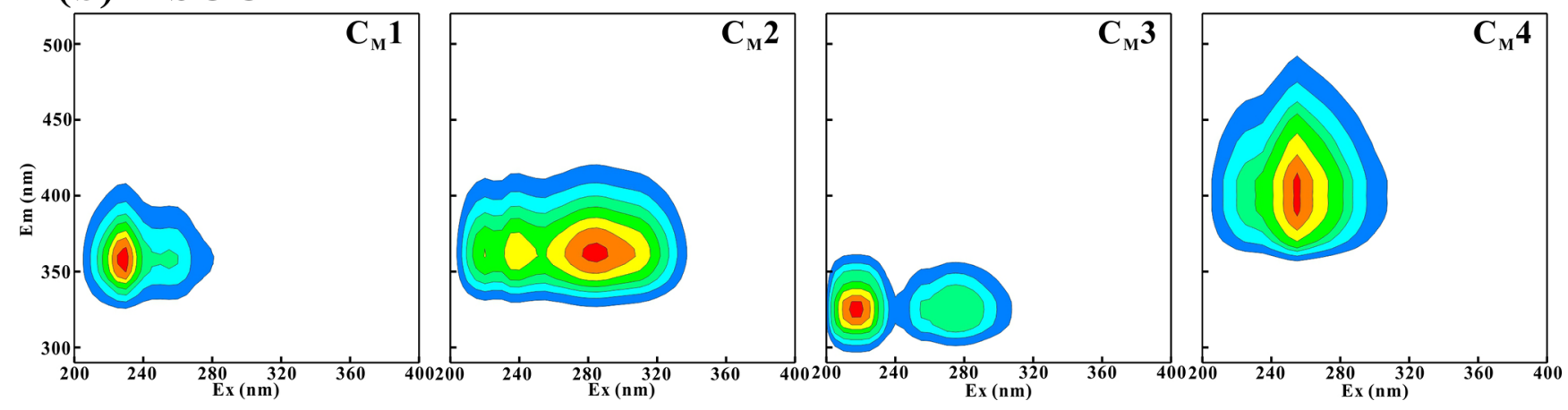

Figure 3. Four fluorescence components identified by PARAFAC analysis of (a) WSOC and HULIS (C $\left.\mathrm{C}_{\mathrm{W}} 1: \mathrm{C}_{\mathrm{W}} 4\right)$ and (b) MSOC $\left(\mathrm{C}_{\mathrm{M}} 1: \mathrm{C}_{\mathrm{M}} 4\right)$ extracted from $\mathrm{BB}$ and $\mathrm{CC}$ smoke $\mathrm{PM}_{2.5}$ (normalized in Raman unit, R.U.).

et al., 2018) or less oxygenated humic-like species (Chen et al., 2017, 2016). This peak was very weak or unobservable in the EEM fluorescence spectra of the WSOC and HULIS-C fractions, suggesting that the higher intensity of the fluorescence peak was mainly due to water-insoluble organic compounds with a high degree of conjugation and/or aromaticity. As shown in Fig. S2, unlike the EEM spectra of crop straw MSOC, the EEM spectra of the three types of wood branches all displayed two obvious fluorescence peaks (e.g., peaks $\mathrm{T}_{1}$ and $\mathrm{T}_{2}$ ). These differences in the EEM spectra between crop straw and wood burning-derived MSOC might be attributed to their molecular differences, which should be investigated in future studies. The EEM spectra of the four bituminous coal smoke MSOC fractions displayed a similar fluorescence peak $T_{2}$ in the EEM spectra, but only a strong peak $T_{1}$ was observed in the anthracite coal smoke MSOC. These differences indicate that the fluorophores of MSOC were significantly influenced by the type of fuel.

\subsubsection{Identification of PARAFAC components}

PARAFAC analysis further determined the fluorescent components of the water-soluble $\mathrm{BrC}$ fraction (WSOC and HULIS-C) and MSOC. As shown in Fig. 3a, WSOC and HULIS-C generally contained four types of fluorophores $\left(\mathrm{C}_{\mathrm{W}} 1-\mathrm{C}_{\mathrm{W}} 4\right)$. Based on previous studies of BrC EEM in combustion aerosols and ambient aerosols (Chen et al., 2017,
2016; Huo et al., 2018; Qin et al., 2018), these four fluorophores could be assigned to two protein-like substances $\left(\mathrm{C}_{\mathrm{W}} 1\right.$ and $\left.\mathrm{C}_{\mathrm{W}} 2\right)$, one polyphenol-like component $\left(\mathrm{C}_{\mathrm{W}} 3\right)$, and one humic-like compound $\left(\mathrm{C}_{\mathrm{W}} 4\right)$. The Ex an Em maximum of $\mathrm{C}_{\mathrm{W}} 1$ was located at 230 and $365 \mathrm{~nm}$, respectively, in region II and was confirmed to be protein-like UV fluorophores. $\mathrm{C}_{\mathrm{W}} 2(\mathrm{Ex}=270 \mathrm{~nm}, \mathrm{Em}=350 \mathrm{~nm})$ was placed in region IV and was determined to be tryptophan-like or microbial byproduct compounds (Chen et al., 2016; Li et al., 2020a), which have been identified in aerosol water-soluble organic matter (WSOM) (Chen et al., 2016; Matos et al., 2015) and BB-derived primary and secondary WSOM (Huo et al., 2018). $\mathrm{C}_{\mathrm{W}} 3(\mathrm{Ex}=205$ and $275 \mathrm{~nm}, \mathrm{Em}=330 \mathrm{~nm})$ was located in regions I and IV and had the characteristics of aromatic protein-like fluorophores or polyphenol-like components, most likely representing the fluorescence properties of polyphenol-like components or compounds containing phenoxy groups (Mostofa et al., 2011). $\mathrm{C}_{\mathrm{W}} 4(\mathrm{Ex}=215-$ $320 \mathrm{~nm}, \mathrm{Em}=415 \mathrm{~nm}$ ) was located in the area where regions III and V overlap. These overlapping peaks were assigned to strong humic-like species fluorescence with an excitation wavelength equals $245 \mathrm{~nm}$ and two weaker shoulder peaks (Chen et al., 2016; Li et al., 2020a; Qin et al., 2018; Huo et al., 2018; Fan et al., 2020); therefore, $\mathrm{C}_{\mathrm{W}} 4$ was associated with typical humic-like fluorophores. In summary, the fluorescence components identified in the WSOC and HULIS- 
$\mathrm{C}$ fractions suggested that protein-like and humic-like substances were the two major backbone components in watersoluble BrC fractions.

As shown in Fig. 3b, four independent fluorescence components were also identified by PARAFAC analysis of MSOC $\left(\mathrm{C}_{\mathrm{M}} 1-\mathrm{C}_{\mathrm{M}} 4\right)$. These components were similar to those of WSOC and HULIS-C, especially the positioning of the main peaks of the four fluorescent fluorophores. However, some small differences for component $2\left(\mathrm{C}_{\mathrm{W}} 2\right.$ and $\left.\mathrm{C}_{\mathrm{M}} 2\right)$ and component $4\left(\mathrm{C}_{\mathrm{W}} 4\right.$ and $\left.\mathrm{C}_{\mathrm{M}} 4\right)$ fluorophores were also observed. Unlike $\mathrm{C}_{\mathrm{W}} 2$ in WSOC and HULIS-C, $\mathrm{C}_{\mathrm{M}} 2$ in MSOC had its Ex and Em maximum at 285 and $360 \mathrm{~nm}$, respectively, which was assigned to tryptophan-like compounds (Fan et al., 2020; Qin et al., 2018). In addition, two lower intensities of peaks at a lower excitation wavelength were also detected. The position of this fluorescence was closer to that of the typical tryptophan-like chromophores in aquatic DOM (Murphy et al., 2010). $\mathrm{C}_{\mathrm{M}} 4$ in MSOC had a strong peak $(E x=255 \mathrm{~nm}, E m=395 \mathrm{~nm})$ but without the shoulder peaks observed for $\mathrm{C}_{\mathrm{W}} 4$ in WSOC (Chen et al., 2016; Hou et al., 2018).

The relative contributions of individual chromophores identified by PARAFAC analysis were calculated to express the relative contribution of each independent chromophore to the overall fluorescence properties and are shown in Fig. 4. The protein-like fluorescence group (components 1 and 2), which were located at low emission wavelengths, dominated the fluorophores of the $\mathrm{BrC}$ fractions in most $\mathrm{BB}$ and $\mathrm{CC}$ smoke samples. As shown in Fig. 4, the contributions of protein-like substances in WSOC, HULIS-C, and MSOC were $47 \%-80 \%, 44 \%-87 \%$, and $42 \%-70 \%$ (except CS MSOC), respectively, which were higher than the contributions of polyphenol-like or humic-like substances in the same $\mathrm{BrC}$ fraction. These results are similar to the results reported for $\mathrm{BrC}$ from biomass combustion emissions in previous studies (Huo et al., 2018; Fan et al., 2020). However, they were significantly different from the EEM-PARAFAC properties of $\mathrm{BrC}$ in ambient aerosols, in which component 4 was the most abundant chromophore (Chen et al., 2016; Li et al., 2020a). However, component 4 accounted for only $13 \%-33 \%$ (except CS MSOC) and 3.8\%-31\% of the $\mathrm{BB}$ and $\mathrm{CC} \mathrm{BrC}$ fluorescence intensities, respectively, which were significantly lower than those reported previously in ambient aerosols (30\%-38\%) (Li et al., 2020a). Moreover, the contribution of polyphenol-like chromophores was $4.0 \%-39 \%$ and was comparable to that of ambient aerosols (18\%-26\%) (Li et al., 2020a; Chen et al., 2016). It is obvious that the four fluorescent components were all detected in the $\mathrm{BrC}$ fractions in combustion-derived smoke particles and atmospheric aerosols; however, the protein-like compounds were the dominant fluorophores in combustionderived $\mathrm{BrC}$, whereas a relatively higher content of humiclike fluorophores was identified in ambient aerosol $\mathrm{BrC}$. These differences may be due to the influence of various sources and atmospheric chemical processes on fluorophores (Li et al., 2020a; Fan et al., 2020).

Furthermore, some differences were also observed among the $\mathrm{BrC}$ fractions derived from different sources. As shown in Fig. 4, the water-soluble BrC (WSOC and HULIS-C) from wood burning had a relatively higher content of component 3 than the water-soluble BrC from crop straw burning, which may be associated with the relatively large amount of lignin components in wood materials. In addition, even though their maturity was very different, there was no regular trend in the relative content of the fluorescent groups.

\section{4 $\quad{ }^{1}$ H-NMR spectroscopy}

${ }^{1} \mathrm{H}$ NMR is an important analytical tool for the investigation of the functional groups of WSOC and HULIS in rural/urban aerosols (Fan et al., 2016; Zou et al., 2020) and rainwater (Santos et al., 2009, 2012). The typical ${ }^{1} \mathrm{H}-\mathrm{NMR}$ spectra of the WSOC, HULIS-C, and MSOC fractions in smoke emitted from BB crop straw (e.g., WS) and CC (e.g., B-1) are shown in Fig. 5, and the ${ }^{1} \mathrm{H}-\mathrm{NMR}$ spectra of other $\mathrm{BB}$ and $\mathrm{CC} \mathrm{BrC}$ fractions are shown in Fig. S3. These BrC fractions had ${ }^{1} \mathrm{H}-\mathrm{NMR}$ spectra similar to those derived from atmospheric HULIS and/or WSOC in rainwater (Santos et al., 2009, 2012), BB aerosols (Fan et al., 2016), and ambient aerosols in urban and rural regions (Zou et al., 2020).

As shown in Fig. 5, the ${ }^{1} \mathrm{H}-\mathrm{NMR}$ spectra were mainly composed of several distinct sharp peaks superimposed on an unresolved broad band. According to previous studies and reference NMR spectra (Zou et al., 2020; Chalbot et al., 2014a, 2016), these sharp peaks can be ascribed to lowmolecular-weight organic compounds, such as levoglucosan $(\delta 3.52, \delta 3.67, \delta 4.08$, and $\delta 5.45 \mathrm{ppm})$, glucose $(\delta 3.88-\delta 3.91$ and $\delta 3.81-\delta 3.85 \mathrm{ppm})$, and fructose $(\delta 3.79-\delta 3.84 \mathrm{ppm})$ associated with $\mathrm{BB}$ emissions; phthalic acid $(\delta 7.45-\delta 7.47$ and $\delta 7.58 \mathrm{ppm})$ and terephthalic acid $(\delta 8.01 \mathrm{ppm})$ associated with anthropogenic activity; and the $\mathrm{CH}_{3}$ in trimethylamine $(\delta 2.71$ and $\delta 2.89 \mathrm{ppm})$, dimethylamine $(\delta 2.72 \mathrm{ppm})$, and monomethylamine $(\delta 2.55 \mathrm{ppm})$ co-emitted with ammonia. The relatively few and/or weak sharp peaks in the ${ }^{1} \mathrm{H}$ NMR spectra of HULIS-C compared with those of WSOC may be the result of low-molecular-weight organic compounds that have been removed from HULIS-C through SPE isolation. In addition, all BB-derived WSOCs had a high intensity of sharp peaks associated with carbohydrates, such as levoglucosan, glucose, and fructose resonances, which may be released from the thermal reactions of biopolymers, such as cellulose. As a comparison, several peaks $(\delta 0.90$ and $\delta 1.35 \mathrm{ppm}$ ) were observed in MSOC and were mainly located in the aliphatic region. These peaks were weaker in WSOC and HULIS-C, suggesting that more less polar aliphatic compounds were present in the MSOC fraction.

Despite some sharp peaks being identified, most of the signals in the ${ }^{1} \mathrm{H}$-NMR spectra of the $\mathrm{BrC}$ fractions presented a continuous unresolved distribution, suggesting that 


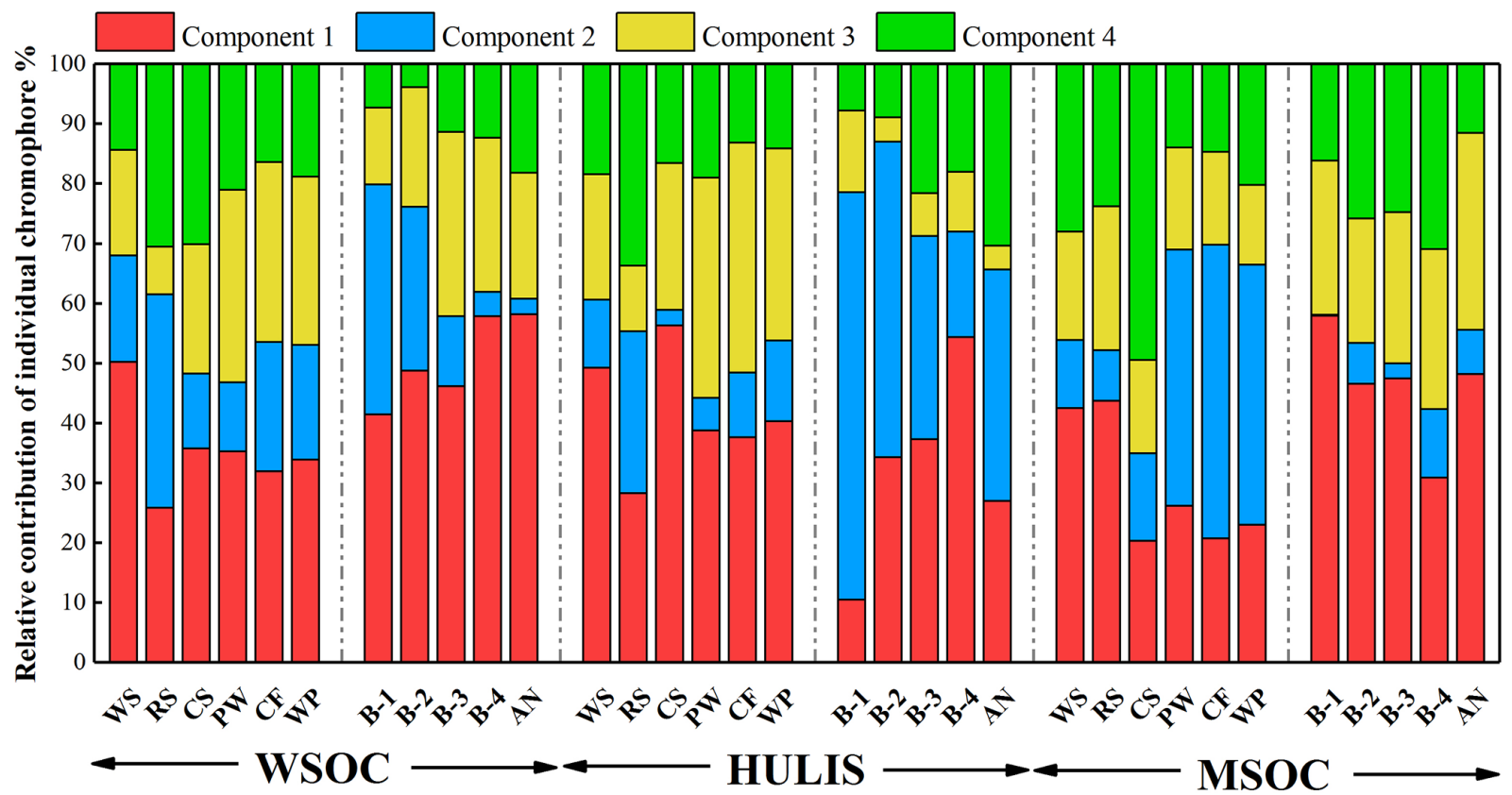

Figure 4. Relative contribution calculated by $F_{\max }$ of individual chromophores analyzed by PARAFAC. Components $1-4$ represent $\mathrm{C}_{\mathrm{W}} 1-4$ for water-soluble $\mathrm{BrC}$ (WSOC and HULIS) and $\mathrm{C}_{\mathrm{M}} 1-4$ for methanol-soluble $\mathrm{BrC}$ (MSOC), respectively.

Table 2. The proton species in the BrC fractions (WSOC, HULIS, and MSOC) of smoke samples.

\begin{tabular}{|c|c|c|c|c|c|c|c|c|c|c|c|c|c|}
\hline & \multirow[b]{2}{*}{ Samples } & \multicolumn{4}{|c|}{ WSOC } & \multicolumn{4}{|c|}{ HULIS } & \multicolumn{4}{|c|}{ MSOC } \\
\hline & & $\begin{array}{r}\mathrm{R}-\mathrm{H} \\
0.6-2.0^{\mathrm{a}}\end{array}$ & $\begin{array}{r}\mathrm{H}-\mathrm{C}-\mathrm{C}= \\
2.0-3.2\end{array}$ & $\begin{array}{r}\mathrm{H}-\mathrm{C}-\mathrm{O} \\
3.4-4.4\end{array}$ & $\begin{array}{r}\mathrm{Ar}-\mathrm{H} \\
6.5-8.5\end{array}$ & $\begin{array}{r}\mathrm{R}-\mathrm{H} \\
0.6-2.0\end{array}$ & $\begin{array}{r}\mathrm{H}-\mathrm{C}-\mathrm{C}= \\
2.0-3.2\end{array}$ & $\begin{array}{r}\mathrm{H}-\mathrm{C}-\mathrm{O} \\
3.4-4.4\end{array}$ & $\begin{array}{r}\mathrm{Ar}-\mathrm{H} \\
6.5-8.5\end{array}$ & $\begin{array}{r}\mathrm{R}-\mathrm{H} \\
0.6-2.0\end{array}$ & $\begin{array}{r}\mathrm{H}-\mathrm{C}-\mathrm{C}= \\
2.0-3.2\end{array}$ & $\begin{array}{r}\mathrm{H}-\mathrm{C}-\mathrm{O} \\
3.4-4.4\end{array}$ & $\begin{array}{r}\mathrm{Ar}-\mathrm{H} \\
6.5-8.5\end{array}$ \\
\hline \multirow[t]{6}{*}{ Biomass burning } & WS & $16^{\mathrm{b}}$ & 27 & 42 & 14 & 19 & 32 & 21 & 27 & 44 & 26 & 16 & 14 \\
\hline & RS & 24 & 27 & 34 & 14 & 26 & 31 & 14 & 29 & 46 & 30 & 13 & 11 \\
\hline & CS & 15 & 22 & 46 & 17 & 18 & 28 & 31 & 24 & 47 & 29 & 15 & 9 \\
\hline & PW & 14 & 22 & 48 & 17 & 15 & 25 & 42 & 18 & 40 & 30 & 19 & 11 \\
\hline & $\mathrm{CF}$ & 11 & 17 & 54 & 18 & 14 & 26 & 36 & 23 & 41 & 28 & 18 & 13 \\
\hline & WP & 12 & 22 & 48 & 19 & 14 & 21 & 31 & 34 & 44 & 29 & 17 & 10 \\
\hline \multirow[t]{5}{*}{ Coal combustion } & B-1 & 18 & 41 & 9.0 & 32 & 17 & 40 & 5.0 & 37 & 40 & 28 & 2.0 & 30 \\
\hline & B-2 & 17 & 35 & 22 & 25 & 26 & 39 & 5.0 & 30 & 33 & 30 & 3.0 & 33 \\
\hline & B-3 & 17 & 39 & 14 & 30 & 22 & 34 & 8.0 & 35 & 34 & 30 & 2.0 & 33 \\
\hline & B-4 & 13 & 27 & 34 & 25 & 20 & 36 & 13 & 30 & 32 & 27 & 3.0 & 39 \\
\hline & AN & 15 & 33 & 20 & 32 & 18 & 37 & 12 & 33 & 38 & 28 & 2.0 & 32 \\
\hline
\end{tabular}

${ }^{\mathrm{a}}$ chemical shift: ppm. ${ }^{\mathrm{b}}$ percentage of each type of protons $(\%)$.

BrC consists of a complex mixture of organic substances (Fan et al., 2016; Chalbot et al., 2014a, 2016). As shown in Fig. 5, the functional groups of smoke BrC could be divided into four representative categories: (1) $\mathrm{R}-\mathrm{H}$ with aliphatic protons in alkyl chains (0.6-1.9 ppm), including methyl $\left(\mathrm{R}-\mathrm{CH}_{3}\right)$ protons, methylene $\left(\mathrm{R}-\mathrm{CH}_{2}\right)$ protons, and methyne $(\mathrm{R}-\mathrm{CH}$ ) protons; (2) $\mathrm{H}-\mathrm{C}-\mathrm{C}=$ with aliphatic protons bound to carbon atoms adjacent to unsaturated groups (1.9-3.2 ppm), including carbonyl $(\mathrm{H}-\mathrm{C}-\mathrm{C}=\mathrm{O})$ and imino $(\mathrm{H}-\mathrm{C}-\mathrm{C}=\mathrm{N})$ groups or aromatic rings; (3) $\mathrm{H}-\mathrm{C}-\mathrm{O}$ with protons bound to oxygenated aliphatic carbons atoms in alcohols, polyols, ethers, and esters (3.4-4.4 ppm), generally indicating that carbohydrates and ethers were present in organic matter; and (4) $\mathrm{Ar}-\mathrm{H}$ with protons bound to aromatic carbon atoms (6.5-8.5 ppm) (Fan et al., 2016; Zou et al., 2020). The distribution of the four types of protons was obtained by integrating the area of the observed ${ }^{1} \mathrm{H}-\mathrm{NMR}$ bands for each sample and is shown in Table 2. These functional groups were also observed in the ${ }^{1} \mathrm{H}-\mathrm{NMR}$ spectra of HULIS in ambient aerosols. In general, HULIS in ambient aerosols (Chalbot et al., 2014b, 2016) and rainwater (Santos et al., 2012) were characterized by the predominance of $\mathrm{H}-\mathrm{C}(41 \%-60 \%)$, moderate contents of $\mathrm{H}-\mathrm{C}-\mathrm{C}=(25 \%-$ $34 \%)$ and $\mathrm{H}-\mathrm{C}-\mathrm{O}(4.0 \%-49 \%)$, and a lesser contribution of $\mathrm{Ar}-\mathrm{H}(2.0 \%-6.0 \%)$. However, it was obvious that the relative content of $\mathrm{Ar}-\mathrm{H}$ groups (18\%-37\%) in HULIS-C from both combustion processes (BB and $\mathrm{CC}$ ) was higher than the levels in ambient HULIS (Table 2), which suggests 

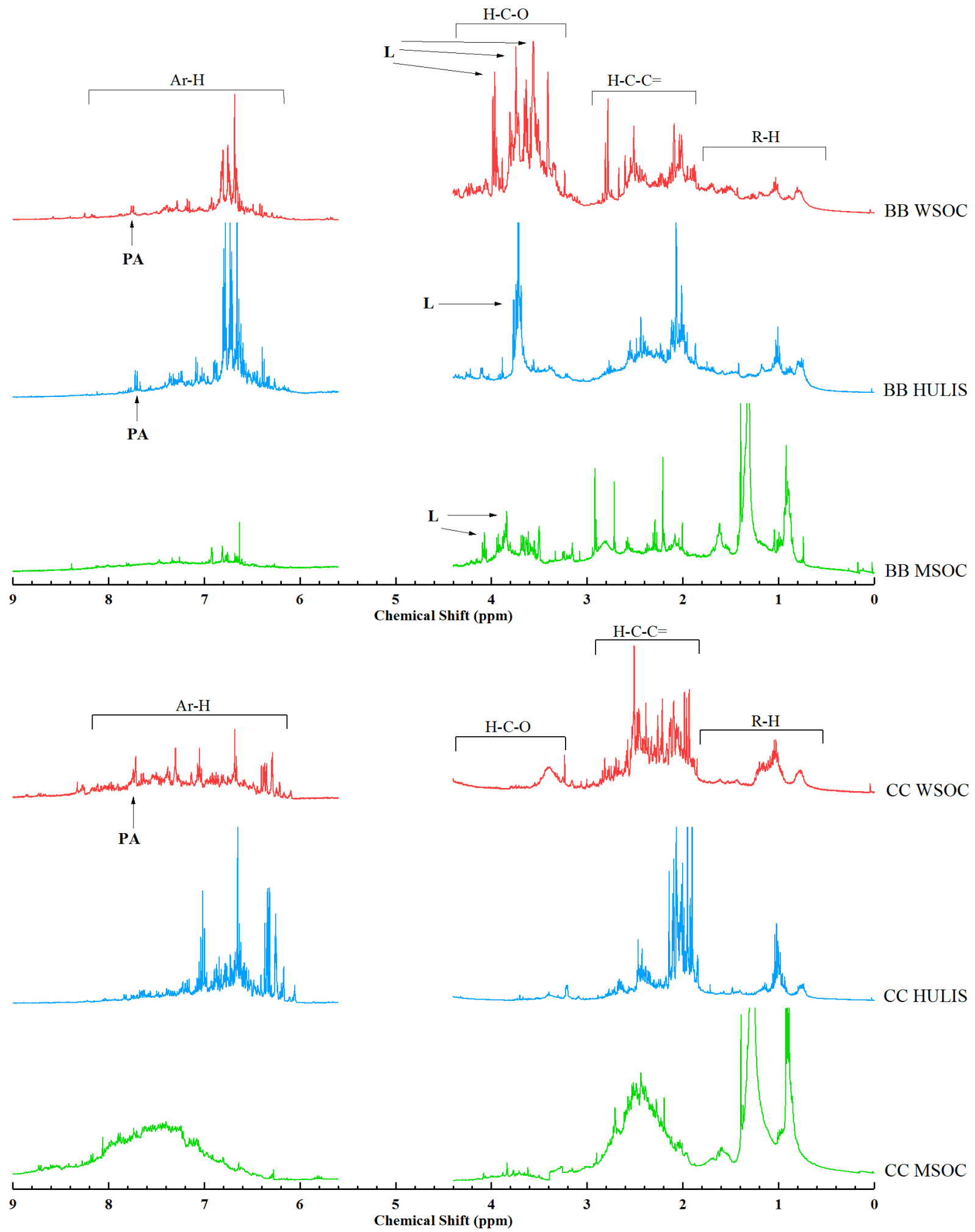

Figure 5. ${ }^{1} \mathrm{H}-\mathrm{NMR}$ spectra of WSOC, HULIS, and MSOC in typical biomass burning and coal combustion smoke samples (BB: wheat straw; CC: B-1 coal). The segment from 4.40 to $5.60 \mathrm{ppm}$ was removed for NMR spectra due to $\mathrm{MeOH}$ and $\mathrm{H}_{2} \mathrm{O}$ residues. The peaks were assigned to specific compounds as follows: levoglucosan (L) and phthalic acid (PA). 
that BB- and CC-derived HULIS-C contained more aromatic structures than ambient HULIS. This was consistent with reports that more aromatic structures are observed in HULIS in colder season aerosol particles in northern China, which may be related to the amount of residential coal and straw combustion (Li et al., 2018; Sun et al., 2017).

As shown in Table 2, the relative contents of the four functional groups (i.e., $\mathrm{R}-\mathrm{H}, \mathrm{H}-\mathrm{C}-\mathrm{C}=, \mathrm{H}-\mathrm{C}-\mathrm{O}$, and $\mathrm{Ar}-\mathrm{H}$ ) varied with the type of $\mathrm{BrC}$. For example, BB WSOC was always characterized by a relatively high level of oxygenated $\mathrm{H}-\mathrm{C}-\mathrm{O}$ groups and a relatively low level of aliphatic $\mathrm{R}-\mathrm{H}$ groups compared with the corresponding MSOC extracted with methanol. As shown in Fig. 5, several strong signals in aliphatic $\mathrm{R}-\mathrm{H}$ were also identified in MSOC, but they were weaker in the WSOC fraction. This was considered reasonable because the less polar aliphatic compounds were difficult to dissolve in water but could be extracted by methanol. As the hydrophobic fraction of WSOC, HULIS-C contained a relatively higher content of the $\mathrm{Ar}-\mathrm{H}$ group and a relatively lower content of the oxygenated $\mathrm{H}-\mathrm{C}-\mathrm{O}$ group than the original WSOC for all BB and CC smoke samples. This was due to most of the low-molecular-weight oxygenated compounds not being retained by the hydrophilic-lipophilic balance cartridges and the enrichment of aromatic species (Fan et al., 2016; Zou et al., 2020).

Some distinct differences in the distribution of functional groups were also observed among the $\mathrm{BrC}$ fractions from $\mathrm{BB}$ and CC. As shown in Fig. 5, several oxygenated compounds (e.g., levoglucosan) were identified, with higher-intensity signals in the BB WSOC fraction, but they were weaker in the WSOC fraction from $\mathrm{CC}$. The relative content of the $\mathrm{H}-\mathrm{C}-\mathrm{O}$ group was in the range of $34 \%-54 \%$ for the six BB WSOCs, which was higher than the values $(9.0 \%-34 \%)$ for the five CC WSOCs. These oxygenated aliphatic compounds were mainly assigned to carbohydrates and polyols that may be caused by the degradation of biomass polymers such as cellulose (Fan et al., 2012, 2016; Lin et al., 2016). In contrast, the $\mathrm{BrC}$ fractions from $\mathrm{CC}$ indicated a relatively higher level of unsaturated functional groups (Table 2). For example, there was a relatively higher content of $\mathrm{Ar}-\mathrm{H}(30 \%-$ $37 \%)$ and $\mathrm{H}-\mathrm{C}-\mathrm{C}=(34 \%-40 \%)$ in the smoke HULIS-C from $\mathrm{CC}$ than from $\mathrm{BB}$, indicating that $\mathrm{CC}$ HULIS-C contained more unsaturated structures, such as aromatic structures and unsaturated aliphatics (Wu et al., 2014; Dong et al., 2021; Huang et al., 2020).

\subsection{Oxidative potential}

The oxidative potential of the BB- and CC-derived $\mathrm{BrC}$ fractions (i.e., WSOC, HULIS-C, and MSOC) was investigated through a DTT assay, and the results are shown in Table S2 and Fig. 6. The DTT $\mathrm{m}$ value of WSOC ranged from $0.5 \mathrm{pmol} / \mathrm{min} / \mu \mathrm{g}$ (B-3) to $7.4 \mathrm{pmol} / \mathrm{min} / \mu \mathrm{g}$ (CS) with a mean of $3.8 \mathrm{pmol} / \mathrm{min} / \mu \mathrm{g}$. These $\mathrm{DTT}_{\mathrm{m}}$ values are comparable with those for the water-soluble fractions of $\mathrm{BB}, \mathrm{CC}$, and diesel

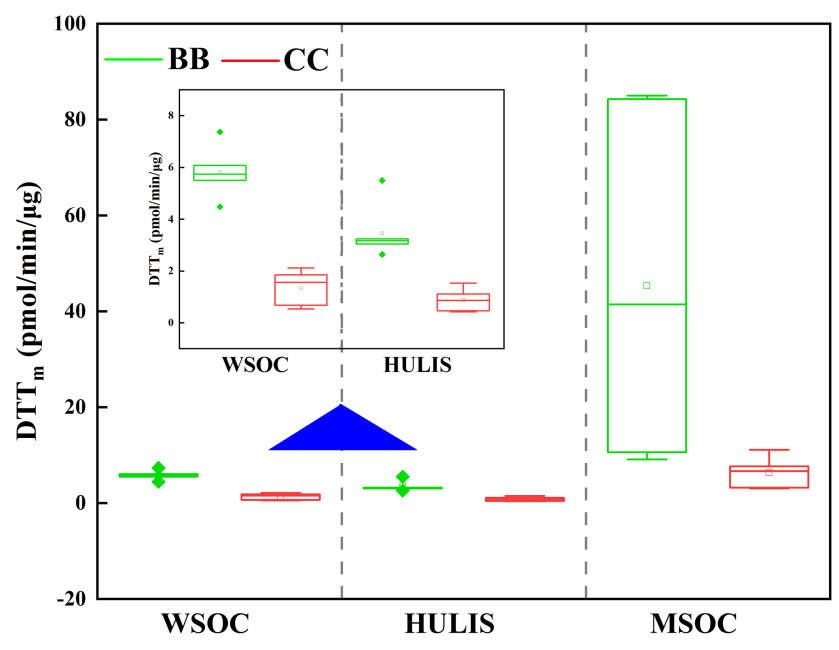

Figure 6. Results of DTT assay conducted on the WSOC, HULIS and MSOC of smoke $\mathrm{PM}_{2.5}$; the values were normalized by the mass of smoke $\mathrm{PM}_{2.5}$. Above the blue triangle symbol is the result coordinates of WSOC and HULIS to be enlarged.

soot $(1.4 \pm 0.6,2.1 \pm 2.3$ and $1.1 \pm 0.4 \mathrm{pmol} / \mathrm{min} / \mu \mathrm{g})(\mathrm{R} . \mathrm{Li}$ et al., 2019; Zhu et al., 2019) but were much lower than the ranges of $14-25 \mathrm{pmol} / \mathrm{min} / \mu \mathrm{g}$ in Los Angeles wildfire aerosol samples, $22-68 \mathrm{pmol} / \mathrm{min} / \mu \mathrm{g}$ in Atlanta $\mathrm{PM}_{2.5}$ samples, and $0.13 \pm 0.10 \mathrm{nmol} / \mathrm{min} / \mu \mathrm{g}$ in Beijing $\mathrm{PM}_{2.5}$ samples (Verma et al., 2012; Bates et al., 2019, Yu et al., 2019). These results suggested that the water-soluble fraction from BB and $\mathrm{CC}$ in this study had a weaker ROS generation capacity than ambient aerosols, which was likely due to the differences in the chemical composition of water-soluble fractions in BB and $\mathrm{CC}$ smoke particles and ambient aerosols (Lin and Yu, 2011, 2019; Dou et al., 2015; Wong et al., 2019). In general, ambient aerosols contain various sources, and the contribution of other sources, such as vehicle emissions or anthropogenic emissions, and transition metals (e.g., $\mathrm{Fe}, \mathrm{Cu}$ ) could increase the ability of atmospheric water-soluble fractions to produce ROS (Ma et al., 2018; R. Li et al., 2019). In addition, because of the evaporative loss of non- or less-DTT active semivolatile organic compounds, the DTT activities of BB-derived water-soluble fractions were enhanced during the aging process (Wong et al., 2019).

The $\mathrm{DTT}_{\mathrm{m}}$ values of BB- and CC-derived HULIS-C ranged from $0.5 \mathrm{pmol} / \mathrm{min} / \mu \mathrm{g}$ (B-3) to $5.5 \mathrm{pmol} / \mathrm{min} / \mu \mathrm{g}$ (RS) with a mean of $2.3 \mathrm{pmol} / \mathrm{min} / \mu \mathrm{g}$. These values were lower than the range $(15-45 \mathrm{pmol} / \mathrm{min} / \mu \mathrm{g})$ previously reported for ambient HULIS measured with the same DTT assay (Lin and Yu, 2011; Ma et al., 2018; Verma et al., 2012). As an important component of WSOC, the DTT activity of HULIS-C accounted $63.1 \% \pm 15.5 \%$ (41.4\%-90.6\%) for that of WSOC in the BB and $\mathrm{CC}$ samples. These values of $\mathrm{DTT}_{\mathrm{m}, \text { HULIS }}$ DTT $_{\mathrm{m}, \text { WSOC }}$ were always higher than the organic carbon contribution of HULIS-C to WSOC for the same sample (Table 1), therefore indicating that hydropho- 
bic HULIS-C was an important redox-active fraction in the BB- and CC-derived WSOC compounds. This result was comparable with the higher oxidative contribution $(64 \%)$ of HULIS-C following water extracts from ambient aerosols in Atlanta (Verma et al., 2012). As reviewed by Win et al. (2018), this phenomenon can be explained by the specific organic species and functional groups with DTT activity in HULIS-C. As described in previous studies and in this study, the hydrophobic organic fractions isolated by the SPE column are mainly comprised of aromatic compounds (Sannigrahi et al., 2006; Fan et al., 2016; Huo et al., 2018). These compounds most likely include some of the redoxactive species such as nitro-PAHs and quinones (Verma et al., 2012), which can catalyze the oxidation of cellular antioxidants and generate ROS (Verma et al., 2012; Lin and $\mathrm{Yu}, 2011)$. In addition, as the charge transfer intermediate, the reversible redox sites in HULIS lead to continuous ROS production (Ma et al., 2018; Lin and Yu, 2011).

The $\mathrm{DTT}_{\mathrm{m}}$ values of MSOC were in the range of $3.1 \mathrm{pmol} / \mathrm{min} / \mu \mathrm{g}$ (B-4) to $84 \mathrm{pmol} / \mathrm{min} / \mu \mathrm{g}$ (RS). These values were comparable to those reported in previous studies involving atmospheric aerosol methanol extracts ( $\sim 55 \mathrm{pmol} / \mathrm{min} / \mu \mathrm{g}$ ) (Verma et al., 2012). As shown in Fig. 6, the $\mathrm{DTT}_{\mathrm{m}}$ values of MSOC were much higher than those of WSOC and HULIS-C from the same smoke samples, which suggested that the water-insoluble components possessed significant oxidative properties that are relevant in toxicological studies (Verma et al., 2012). These results were consistent with the results of previous studies showing that water-insoluble compounds made the largest contribution to the oxidative potential (Verma et al., 2012, 2015).

The $\mathrm{DTT}_{\mathrm{m}}$ values of the $\mathrm{BrC}$ fractions varied with the type of fuel. As shown in Table $\mathrm{S} 2$, the $\mathrm{DTT}_{\mathrm{m}}$ values of BB WSOC were $4.5-7.4 \mathrm{pmol} / \mathrm{min} / \mu \mathrm{g}$, which was significantly higher than the range of $0.5-2.1 \mathrm{pmol} / \mathrm{min} / \mu \mathrm{g}$ for $\mathrm{CC}$ WSOC. Similar results were also observed for the HULIS and MSOC fractions (Fig. 6). These results indicated that the $\mathrm{BrC}$ fractions from $\mathrm{BB}$ had higher oxidative potential values than those from $\mathrm{CC}$ and therefore more readily catalyzed the generation of ROS. Furthermore, no regular variations were observed for the oxidative potential of water-soluble $\mathrm{BrC}$ (e.g., WSOC and HULIS-C) in BB or CC smoke samples, but the MSOC in crop straw smoke had a much higher DTT mass value than the MSOC in smoke samples from wood burning and CC. These differences were associated with the differences in the amounts of redox-active compounds in each $\mathrm{BrC}$ fraction. There is a need for more studies to investigate the relationship between the molecular structures in BB smoke $\mathrm{BrC}$ and their DTT activities.

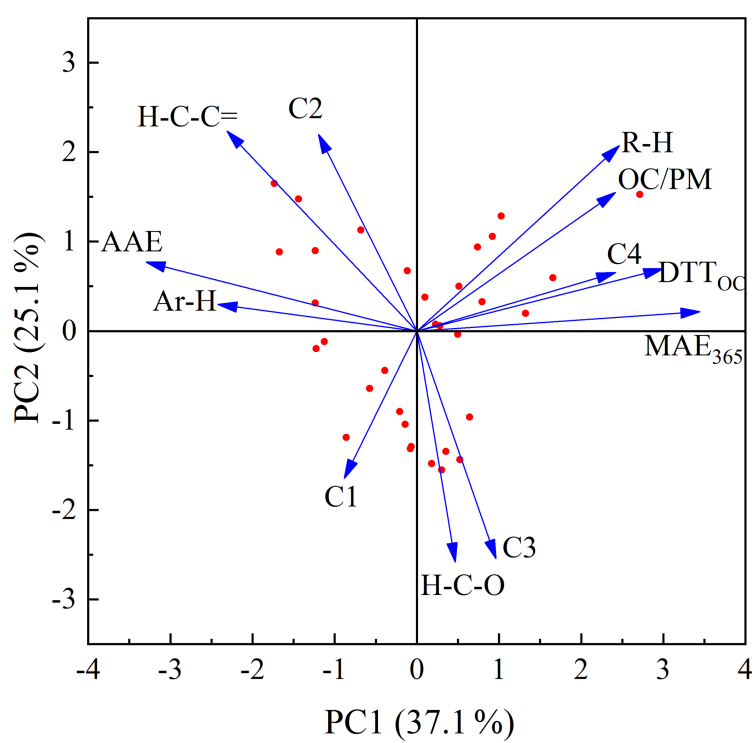

Figure 7. Principal component analysis results for the carbon massnormalized OP activities and chemical characteristics of $\mathrm{BrC}$ compounds in smoke particles.

\subsection{Correlation between oxidative potential and chemical compositions of $\mathrm{BrC}$}

The $\mathrm{BrC}$ compounds produced by the $\mathrm{BB}$ and $\mathrm{CC}$ processes generally have different oxidative potentials. The oxidative potential values of water-soluble $\mathrm{BrC}$ (WSOC and HULISC) were much lower than those in MSOC, and the $\mathrm{BB}$ $\mathrm{BrC}$ fractions had higher oxidative potential values than $\mathrm{CC}$ $\mathrm{BrC}$ fractions. These results suggested that $\mathrm{BrC}$ from different sources exhibited distinct redox properties (Lin and $\mathrm{Yu}, 2011)$. To elucidate the association of chemical characteristics with the oxidative potential of $\mathrm{BB}$ and $\mathrm{CC}$, principal component analysis (PCA) and Pearson correlation coefficients were conducted. Because the optical and chemical properties were all obtained based on organic matter rather than PM, the oxidative potential value normalized by the organic carbon mass $\left(\right.$ DTT $_{\text {OC }}$ ) of each fraction was used here to present DTT activities, as well as the capacity to produce ROS. In addition, considering the statistical significance and quantity, the WSOC, HULIS-C, and MSOC data were analyzed together.

The results are shown in Fig. 7 and Table 3. It is obvious that $\mathrm{DTT}_{\mathrm{OC}}$ showed a positive loading for both principal component 1 (PC1) and principal component 2 (PC2), and $\mathrm{DTT}_{\mathrm{OC}}$ was grouped with fluorophores $\mathrm{C} 4$ and $\mathrm{MAE}_{365}$. These results are also given by the Pearson correlation coefficient analysis in which the DTT $_{\text {OC }}$ values showed significant positive correlations with the parameters $\mathrm{MAE}_{365}$ $(R=0.697, p<0.01)$ and $\mathrm{C} 4$ proportion $(R=0.560, p<$ $0.01)$. These results suggested that fluorophore $\mathrm{C} 4$ and highlight-absorbing components may significantly contribute to the DTT activities of $\mathrm{BrC}$ compounds. 
Table 3. Pearson correlation coefficient analysis between oxidation potential and chemical characteristics of $\mathrm{BrC}$.

\begin{tabular}{lll}
\hline & \multicolumn{2}{c}{$\mathrm{DTT}_{\text {OC }}^{\mathrm{a}}$} \\
\cline { 2 - 3 } & $R$ & $p$ \\
\hline MAE $_{365}$ & $0.697^{* *}$ & 0.000 \\
${\text { Fluorescence component 1 }(\%)^{\mathrm{b}}}^{\mathrm{b}}$ & -0.078 & 0.668 \\
Fluorescence component 2 (\%) $^{\mathrm{b}}$ & -0.330 & 0.061 \\
Fluorescence component 3(\%) & 0.151 & 0.402 \\
Fluorescence component 4 $(\%)^{\mathrm{b}}$ & $0.560^{* *}$ & 0.001 \\
$\mathrm{R}-\mathrm{H}(\%)$ & $0.697^{* *}$ & 0.000 \\
$\mathrm{H}-\mathrm{C}=\mathrm{C}(\%)$ & -0.247 & 0.166 \\
$\mathrm{H}-\mathrm{C}-\mathrm{O}(\%)$ & -0.223 & 0.213 \\
$\mathrm{Ar}-\mathrm{H}(\%)$ & $-0.345^{*}$ & 0.049 \\
\hline
\end{tabular}

${ }^{\text {a }}$ DTT $_{\mathrm{OC}}$ values were calculated using the DTT consumption rate divided by the mass of organic carbon. ${ }^{\mathrm{b}}$ Fluorescence components $1-4$ represent florescent fluorophores $1-4\left(\mathrm{C}_{\mathrm{W}} 1-4\right.$ and $\left.\mathrm{C}_{\mathrm{M}} 1-4\right)$ identified by the PARAFAC method. * There was significant correlation in $95 \%$ confidence interval (bilateral) ( $p$ value no more than 0.05$).{ }^{* *}$ There was significant correlation in $99 \%$ confidence interval (bilateral) ( $p$ value no more than 0.01).

Moreover, a significant positive relationship was also observed for $\mathrm{C} 4$ and $\mathrm{MAE}_{365}(R=0.531, p<0.01)$, which indicated that $\mathrm{C} 4$ may be the main substance leading to the light absorption of $\mathrm{BrC}$. As reported previously, $\mathrm{MAE}_{365}$ is related to the aromatic structure of the conjugated system (Andrade-Eiroa et al., 2013; Fan et al., 2018), and fluorophore $\mathrm{C} 4$ was considered to be a highly oxygenated species containing more carbonyl and carboxyl groups (Chen et al., 2016; Li et al., 2020a). Therefore, the $\mathrm{C} 4$ component may mainly comprise chemical species with a conjugated system and highly oxygenated species, such as quinones or aromatic acids, which were believed to be the key components for the enhancement of the ability of $\mathrm{BrC}$ to produce $\mathrm{ROS}$ (Lin and Yu, 2011; Jiang et al., 2016; Verma et al., 2012). These results also explained that the water-soluble $\mathrm{BrC}$ fractions in BB and CC smoke showed a relatively lower DTT consumption rate than those in ambient aerosols, in which distinctly higher contents of fluorophore $\mathrm{C} 4$ were observed in the water-soluble fraction (Matos et al., 2015; Chen et al., 2016).

We note that a positive correlation was observed between DTT $_{\mathrm{OC}}$ and $\mathrm{R}-\mathrm{H}$ and a negative correlation was observed between $\mathrm{DTT}_{\mathrm{OC}}$ and $\mathrm{Ar}-\mathrm{H}$; however, it is scientifically unreasonable. The main reason is that ${ }^{1} \mathrm{H}-\mathrm{NMR}$ spectroscopy only measures the concentrations of nonexchangeable hydrogen functional groups in $\mathrm{BrC}$ compounds. Some organic compounds not carrying nonexchangeable hydrogen atoms, such as carbonyl or carboxylic groups in $\mathrm{BrC}$, cannot be detected by ${ }^{1} \mathrm{H}$ NMR (Chalbot et al., 2014b; Paglione et al., 2014). However, some of these oxygenated functional groups likely have the ability to catalyze the generation of ROS (Lin and Yu, 2011; Verma et al., 2015). In addition, the H/C ratios of different hydrogen functional groups (i.e., $\mathrm{R}-\mathrm{H}$,
$\mathrm{H}-\mathrm{C}-\mathrm{C}=, \mathrm{H}-\mathrm{C}-\mathrm{O}$, and $\mathrm{Ar}-\mathrm{H}$ ) are very different; thus, the relative abundances of hydrogen functional groups are difficult to compare with the carbon functional groups in $\mathrm{BrC}$ compounds (Decesari et al., 2007). Therefore, it is necessary that other NMR techniques such as solution-state ${ }^{13} \mathrm{C}$ NMR and two-dimensional heteronuclear $\left({ }^{1} \mathrm{H}_{-}{ }^{13} \mathrm{C}\right)$ NMR be used to explore the chemical functional groups associated with the oxidative potential of $\mathrm{BrC}$ in future studies.

\section{Conclusions}

In this study, the primary $\mathrm{BrC}$ fractions (i.e., WSOC, HULIS$\mathrm{C}$, and MSOC) emitted from BB and CC were comprehensively investigated to determine their content, light absorption, fluorophores, chemical properties, and oxidative potential. The results indicated that both $\mathrm{BB}$ and $\mathrm{CC}$ were important sources of atmospheric $\mathrm{BrC}$. It was found that BB generated more of the water-soluble $\mathrm{BrC}$ fraction, whereas $\mathrm{CC}$ released more of the methanol-soluble $\mathrm{BrC}$ fraction in smoke $\mathrm{PM}_{2.5}$. The results also enhanced our understanding of the optical characteristics, chemical composition, and oxidative potential of the water- and methanol-soluble $\mathrm{BrC}$ fractions. The MSOC fraction had higher MAE 365 values than HULIS$\mathrm{C}$ and WSOC, suggesting that water-insoluble $\mathrm{BrC}$ possessed a stronger light-absorbing capacity. In addition, $\mathrm{BB} \mathrm{BrC}$ generally had higher $\mathrm{MAE}_{365}$ and lower AAE values than the corresponding $\mathrm{CC} \mathrm{BrC}$ fractions, suggesting that the former had a higher light absorption capacity and weaker wavelength dependence. The EEM-PARAFAC analysis identified two protein-like compounds, one polyphenol-like component, and one humic-like compound for all $\mathrm{BrC}$ fractions, among which the protein-like compounds were the dominant components. The ${ }^{1} \mathrm{H}-\mathrm{NMR}$ analysis showed that the $\mathrm{BB}$ and $\mathrm{CC} \mathrm{BrC}$ fractions contained $\mathrm{R}-\mathrm{H}, \mathrm{H}-\mathrm{C}-\mathrm{C}=, \mathrm{H}-\mathrm{C}-\mathrm{O}$, and $\mathrm{Ar}-\mathrm{H}$ groups, among which WSOC and HULIS-C were always characterized by more oxygenated $\mathrm{H}-\mathrm{C}-\mathrm{O}$ groups and fewer aliphatic $\mathrm{R}-\mathrm{H}$ groups than MSOC. In addition, water-soluble $\mathrm{BB} \mathrm{BrC}$ contained more highly oxygenated groups, suggesting that they may have a stronger influence on the binding of metals by organic aerosols. Our study also indicated that MSOC had higher $\mathrm{DTT}_{\mathrm{m}}$ values than WSOC and HULIS-C, suggesting a higher ROS generation capacity. In addition, relatively higher oxidative contributions $(63.1 \% \pm 15.5 \%)$ of HULIS-C in WSOC were observed for all $\mathrm{BB}$ and $\mathrm{CC}$ smoke samples, highlighting that HULIS was a major contributor of ROS production in WSOC. The BB BrC fractions generally had a higher oxidative potential than $\mathrm{CC} B r C$, which may suggest that $\mathrm{BB} \mathrm{BrC}$ was more readily able to catalyze the generation of ROS and therefore lead to more severe harm to human health. More importantly, the PCA and Pearson correlation analysis indicated that highly oxygenated humic-like fluorophore $\mathrm{C} 4$ may be an important DTT active substance in BrC. 
It should be noted that the $\mathrm{BB}$ and $\mathrm{CC} \mathrm{BrC}$ fractions would experience a series of chemical reactions once they are emitted into the atmosphere, resulting in changes to their optical properties and DTT activities. Thus, future studies should focus on the chemical, optical, and oxidative potential characteristics of $\mathrm{BrC}$ during the aging processes with smoke particles in the tropospheric environment (Fan et al., 2020; Wong et al., 2019).

Data availability. The research data can be accessed upon request to the corresponding author (songjzh@gig.ac.cn).

Supplement. The supplement related to this article is available online at: https://doi.org/10.5194/acp-21-13187-2021-supplement.

Author contributions. JS and PP designed the research together. TC, ML, and CZ conducted the combustion experiments. TC, ML, and $\mathrm{CY}$ extracted and analyzed the $\mathrm{BrC}$ fractions. TC and JS wrote the paper. XF, JW, ZY, and PP commented on and revised the paper.

Competing interests. The authors declare that they have no conflict of interest.

Disclaimer. Publisher's note: Copernicus Publications remains neutral with regard to jurisdictional claims in published maps and institutional affiliations.

Acknowledgements. This study was supported by the National Natural Science Foundation of China (41977188 and 41673177), the State Key Laboratory of Organic Geochemistry, GIGCAS (SKLOG2020-3), and Guangdong Foundation for Program of Science and Technology Research (2019B121205006). We greatly appreciate the assistance of two anonymous reviewers for the helpful comments that greatly improved the quality of this article.

Financial support. This research has been supported by the NationalNatural Science Foundation of China (41977188 and 41673177), the State Key Laboratory of Organic Geochemistry, GIGCAS(SKLOG2020-3), and Guangdong Foundation for Program of Science and Technology Research (2019B121205006).

Review statement. This paper was edited by Arthur Chan and reviewed by two anonymous referees.

\section{References}

Alexander, D. T. L., Crozier, P. A., and Anderson, J. R.: Brown carbon spheres in East Asian outflow and their optical properties, Science, 321, 833-836, https://doi.org/10.1126/science.1155296, 2008.

Andrade-Eiroa, Á., Canle, M., and Cerdá, V.: Environmental Applications of Excitation-Emission Spectrofluorimetry: An In-Depth Review I, Appl. Spec. Rev., 48, 1-49, https://doi.org/10.1080/05704928.2012.692104, 2013.

Andreae, M. O. and Gelencsér, A.: Black carbon or brown carbon? The nature of light-absorbing carbonaceous aerosols, Atmos. Chem. Phys., 6, 3131-3148, https://doi.org/10.5194/acp-63131-2006, 2006.

Atwi, K., Mondal, A., Pant, J., Cheng, Z., El Hajj, O., Ijeli, I., Handa, H., and Saleh, R.: Physicochemical properties and cytotoxicity of brown carbon produced under different combustion conditions, Atmos. Environ., 244, 117881, https://doi.org/10.1016/j.atmosenv.2020.117881, 2021.

Bai, Z., Zhang, L., Cheng, Y., Zhang, W., Mao, J., Chen, H., Li, L., Wang, L., and Chen, J.: Water/Methanol-Insoluble Brown Carbon Can Dominate Aerosol-Enhanced Light Absorption in Port Cities, Environ. Sci. Technol., 54, 14889-14898, https://doi.org/10.1021/acs.est.0c03844, 2020.

Bates, J. T., Fang, T., Verma, V., Zeng, L., Weber, R. J., Tolbert, P. E., Abrams, J. Y., Sarnat, S. E., Klein, M., Mulholland, J. A., and Russell, A. G.: Review of Acellular Assays of Ambient Particulate Matter Oxidative Potential: Methods and Relationships with Composition, Sources, and Health Effects, Environ. Sci. Technol., 53, 4003-4019, https://doi.org/10.1021/acs.est.8b03430, 2019.

Chalbot, M.-C. G., Brown, J., Chitranshi, P., Gamboa da Costa, G., Pollock, E. D., and Kavouras, I. G.: Functional characterization of the water-soluble organic carbon of size-fractionated aerosol in the southern Mississippi Valley, Atmos. Chem. Phys., 14, 6075-6088, https://doi.org/10.5194/acp-14-6075-2014, 2014a.

Chalbot, M.-C. G. and Kavouras, I. G.: Nuclear magnetic resonance spectroscopy for determining the functional content of organic aerosols: a review, Environ. Pollut., 191, 232-249, https://doi.org/10.1016/j.envpol.2014.04.034, 2014b.

Chalbot, M.-C. G., Chitranshi, P., da Costa, G. G., Pollock, E., and Kavouras, I. G.: Characterization of water-soluble organic matter in urban aerosol by (1)H-NMR spectroscopy, Atmos. Environ., 128, 235-245, https://doi.org/10.1016/j.atmosenv.2015.12.067, 2016.

Chen, Q., Miyazaki, Y., Kawamura, K., Matsumoto, K., Coburn, S., Volkamer, R., Iwamoto, Y., Kagami, S., Deng, Y., Ogawa, S., Ramasamy, S., Kato, S., Ida, A., Kajii, Y., and Mochida, M.: Characterization of Chromophoric WaterSoluble Organic Matter in Urban, Forest, and Marine Aerosols by HR-ToF-AMS Analysis and Excitation-Emission Matrix Spectroscopy, Environ. Sci. Technol., 50, 10351-10360, https://doi.org/10.1021/acs.est.6b01643, 2016.

Chen, Q., Ikemori, F., Nakamura, Y., Vodicka, P., Kawamura, K., and Mochida, M.: Structural and Light-Absorption Characteristics of Complex Water-Insoluble Organic Mixtures in Urban Submicrometer Aerosols, Environ. Sci. Technol., 51, 82938303, https://doi.org/10.1021/acs.est.7b01630, 2017.

Chen, Q., Wang, M., Wang, Y., Zhang, L., Li, Y., and Han, Y.: Oxidative Potential of Water-Soluble Matter Asso- 
ciated with Chromophoric Substances in $\mathrm{PM}_{2.5}$ over Xi'an, China, Environ. Sci. Technol., 53, 8574-8584, https://doi.org/10.1021/acs.est.9b01976, 2019.

Chen, Q., Li, J., Hua, X., Jiang, X., Mu, Z., Wang, M., Wang, J., Shan, M., Yang, X., Fan, X., Song, J., Wang, Y., Guan, D., and Du, L.: Identification of species and sources of atmospheric chromophores by fluorescence excitation-emission matrix with parallel factor analysis, Sci. Tot. Environ., 718, 137322, https://doi.org/10.1016/j.scitotenv.2020.137322, 2020.

Chen, W., Westerhoff, P., Leenheer, J. A., and Booksh, K.: Fluorescence excitation - Emission matrix regional integration to quantify spectra for dissolved organic matter, Environ. Sci. Technol., 37, 5701-5710, https://doi.org/10.1021/es034354c, 2003.

Chen, Y. and Bond, T. C.: Light absorption by organic carbon from wood combustion, Atmos. Chem. Phys., 10, 1773-1787, https://doi.org/10.5194/acp-10-1773-2010, 2010.

Cheng, Y., He, K. B., Du, Z. Y., Engling, G., Liu, J. M., Ma, Y. L., Zheng, M., and Weber, R. J.: The characteristics of brown carbon aerosol during winter in Beijing, Atmos. Environ., 127, 355-364, https://doi.org/10.1016/j.atmosenv.2015.12.035, 2016.

Cui, X., Zhou, D., Fan, W., Huo, M., Crittenden, J. C., Yu, Z., Ju, P., and Wang, Y.: The effectiveness of coagulation for water reclamation from a wastewater treatment plant that has a long hydraulic and sludge retention times: A case study, Chemosphere, 157, 224-231, https://doi.org/10.1016/j.chemosphere.2016.05.009, 2016.

Decesari, S., Mircea, M., Cavalli, F., Fuzzi, S., Moretti, F., Tagliavini, E., and Facchini, M. C.: Source attribution of water-soluble organic aerosol by nuclear magnetic resonance spectroscopy, Environ. Sci. Technol., 41, 2479-2484, https://doi.org/10.1021/es0617111, 2007.

Dong, Z., Jiang, N., Zhang, R., Xu, Q., Ying, Q., Li, Q., and Li, S.: Molecular characteristics, source contributions, and exposure risks of polycyclic aromatic hydrocarbons in the core city of Central Plains Economic Region, China: Insights from the variation of haze levels, Sci. Tot. Environ., 757, 143885, https://doi.org/10.1016/j.scitotenv.2020.143885, 2021.

Dou, J., Lin, P., Kuang, B. Y., and Yu, J. Z.: Reactive Oxygen Species Production Mediated by Humic-like Substances in Atmospheric Aerosols: Enhancement Effects by Pyridine, Imidazole, and Their Derivatives, Environ. Sci. Technol., 49, 64576465, https://doi.org/10.1021/es5059378, 2015.

Evangeliou, N., Kylling, A., Eckhardt, S., Myroniuk, V., Stebel, K., Paugam, R., Zibtsev, S., and Stohl, A.: Open fires in Greenland in summer 2017: transport, deposition and radiative effects of BC, OC and BrC emissions, Atmos. Chem. Phys., 19, 1393-1411, https://doi.org/10.5194/acp-19-1393-2019, 2019.

Fan, X. J., Song, J. Z., and Peng, P. A.: Comparison of isolation and quantification methods to measure humic-like substances (HULIS) in atmospheric particles, Atmos. Environ., 60, 366374, https://doi.org/10.1016/j.atmosenv.2012.06.063, 2012.

Fan, X., Wei, S., Zhu, M., Song, J., and Peng, P.: Comprehensive characterization of humic-like substances in smoke $\mathrm{PM}_{2.5}$ emitted from the combustion of biomass materials and fossil fuels, Atmos. Chem. Phys., 16, 13321-13340, https://doi.org/10.5194/acp-16-13321-2016, 2016.

Fan, X., Li, M., Cao, T., Cheng, C., Li, F., Xie, Y., Wei, S., Song, J., and Peng, P. a.: Optical properties and oxidative potential of water-and alkaline-soluble brown carbon in smoke particles emitted from laboratory simulated biomass burning, Atmos. Environ., 194, 48-57, https://doi.org/10.1016/j.atmosenv.2018.09.025, 2018.

Fan, X., Yu, X., Wang, Y., Xiao, X., Li, F., Xie, Y., Wei, S., Song, J., and Peng, P. A.: The aging behaviors of chromophoric biomass burning brown carbon during dark aqueous hydroxyl radical oxidation processes in laboratory studies, Atmos. Environ., 205, 918, https://doi.org/10.1016/j.atmosenv.2019.02.039, 2019.

Fan, X., Cao, T., Yu, X., Wang, Y., Xiao, X., Li, F., Xie, Y., Ji, W., Song, J., and Peng, P.: The evolutionary behavior of chromophoric brown carbon during ozone aging of fine particles from biomass burning, Atmos. Chem. Phys., 20, 4593-4605, https://doi.org/10.5194/acp-20-4593-2020, 2020.

Gao, D., Mulholland, J. A., Russell, A. G., and Weber, R. J.: Characterization of water-insoluble oxidative potential of $\mathrm{PM}_{2.5}$ using the dithiothreitol assay, Atmos. Environ., 224, 117327, https://doi.org/10.1016/j.atmosenv.2020.117327, 2020.

Geng, C., Chen, J., Yang, X., Ren, L., Yin, B., Liu, X., and Bai, Z.: Emission factors of polycyclic aromatic hydrocarbons from domestic coal combustion in China, J. Environ. Sci., 26, 160 166, https://doi.org/10.1016/s1001-0742(13)60393-9, 2014.

Hakimzadeh, M., Soleimanian, E., Mousavi, A., Borgini, A., De Marco, C., Ruprecht, A. A., and Sioutas, C.: The impact of biomass burning on the oxidative potential of $\mathrm{PM}_{2.5}$ in the metropolitan area of Milan, Atmos. Environ., 224, 117328, https://doi.org/10.1016/j.atmosenv.2020.117328, 2020.

He, W. and Hur, J.: Conservative behavior of fluorescence EEMPARAFAC components in resin fractionation processes and its applicability for characterizing dissolved organic matter, Water Res., 83, 217-226, https://doi.org/10.1016/j.watres.2015.06.044, 2015.

Hoffer, A., Gelencsér, A., Guyon, P., Kiss, G., Schmid, O., Frank, G. P., Artaxo, P., and Andreae, M. O.: Optical properties of humiclike substances (HULIS) in biomass-burning aerosols, Atmos. Chem. Phys., 6, 3563-3570, https://doi.org/10.5194/acp-6-35632006, 2006.

Hou, C., Shao, L., Hu, W., Zhang, D., Zhao, C., Xing, J., Huang, X., and $\mathrm{Hu}, \mathrm{M}$.: Characteristics and aging of traffic-derived particles in a highway tunnel at a coastal city in southern China, Sci. Tot. Environ., 619, 1385-1393, https://doi.org/10.1016/j.scitotenv.2017.11.165, 2018.

Huang, R. J., Yang, L., Shen, J., Yuan, W., Gong, Y., Guo, J., Cao, W., Duan, J., Ni, H., Zhu, C., Dai, W., Li, Y., Chen, Y., Chen, Q., Wu, Y., Zhang, R., Dusek, U., O'Dowd, C., and Hoffmann, T.: Water-Insoluble Organics Dominate Brown Carbon in Wintertime Urban Aerosol of China: Chemical Characteristics and Optical Properties, Environ. Sci. Technol., 54, 7836-7847, https://doi.org/10.1021/acs.est.0c01149, 2020.

Huo, Y. Q., Li, M., Jiang, M. H., and Qi, W. M.: Light absorption properties of HULIS in primary particulate matter produced by crop straw combustion under different moisture contents and stacking modes, Atmos. Environ., 191, 490-499, https://doi.org/10.1016/j.atmosenv.2018.08.038, 2018.

Izhar, S., Gupta, T., and Panday, A. K.: Improved method to apportion optical absorption by black and brown carbon under the influence of haze and fog at Lumbini, Nepal, on the Indo-Gangetic Plains, Environ. Pollut., 263, 114640, https://doi.org/10.1016/j.envpol.2020.114640, 2020. 
Jiang, H., Jang, M., Sabo-Attwood, T., and Robinson, S. E.: Oxidative potential of secondary organic aerosols produced from photooxidation of different hydrocarbons using outdoor chamber under ambient sunlight, Atmos. Environ., 131, 382-389, https://doi.org/10.1016/j.atmosenv.2016.02.016, 2016.

Kim, H., Kim, J. Y., Jin, H. C., Lee, J. Y., and Lee, S. P.: Seasonal variations in the light-absorbing properties of water-soluble and insoluble organic aerosols in Seoul, Korea, Atmos. Environ., 129, 234-242, https://doi.org/10.1016/j.atmosenv.2016.01.042, 2016.

Kramer, A. J., Rattanavaraha, W., Zhang, Z., Gold, A., Surratt, J. D., and Lin, Y.-H.: Assessing the oxidative potential of isoprene-derived epoxides and secondary organic aerosol, Atmos. Environ., 130, 211-218, https://doi.org/10.1016/j.atmosenv.2015.10.018, 2016.

Kumar, N. K., Corbin, J. C., Bruns, E. A., Massabó, D., Slowik, J. G., Drinovec, L., Močnik, G., Prati, P., Vlachou, A., Baltensperger, U., Gysel, M., El-Haddad, I., and Prévôt, A. S. H.: Production of particulate brown carbon during atmospheric aging of residential wood-burning emissions, Atmos. Chem. Phys., 18, 17843-17861, https://doi.org/10.5194/acp-18-178432018, 2018.

Kumar, V., Rajput, P., and Goel, A.: Atmospheric abundance of HULIS during wintertime in Indo-Gangetic Plain: impact of biomass burning emissions, J. Atmos. Chem., 75, 385-398, https://doi.org/10.1007/s10874-018-9381-4, 2018.

Laskin, A., Laskin, J., and Nizkorodov, S. A.: Chemistry of atmospheric brown carbon, Chem. Rev., 115, 4335-4382, https://doi.org/10.1021/cr5006167, 2015.

Lawaetz, A. J., and Stedmon, C. A.: Fluorescence Intensity Calibration Using the Raman Scatter Peak of Water, Appl. Spec., 63, 936-940, https://doi.org/10.1366/000370209788964548, 2009.

Li, M., Fan, X., Zhu, M., Zou, C., Song, J., Wei, S., Jia, W., and Peng, P.: Abundances and light absorption properties of brown carbon emitted from residential coal combustion in China, Environ. Sci. Technol., 53, 595-603, https://doi.org/10.1021/acs.est.8b05630, 2019.

Li, R., Han, Y., Wang, L., Shang, Y., and Chen, Y.: Differences in oxidative potential of black carbon from three combustion emission sources in China, J. Environ. Manage., 240, 57-65, https://doi.org/10.1016/j.jenvman.2019.03.070, 2019.

Li, X., Han, J., Hopke, P. K., Hu, J., Shu, Q., Chang, Q., and Ying, Q.: Quantifying primary and secondary humic-like substances in urban aerosol based on emission source characterization and a source-oriented air quality model, Atmos. Chem. Phys., 19, 2327-2341, https://doi.org/10.5194/acp-19-2327-2019, 2019.

Li, J., Chen, Q., Hua, X., Chang, T., and Wang, Y.: Occurrence and sources of chromophoric organic carbon in fine particulate matter over Xi' an, China, Sci. Total Environ., 725, 138290, https://doi.org/10.1016/j.scitotenv.2020.138290, 2020a.

Li, J., Zhang, Q., Wang, G., Li, J., Wu, C., Liu, L., Wang, J., Jiang, W., Li, L., Ho, K. F., and Cao, J.: Optical properties and molecular compositions of water-soluble and water-insoluble brown carbon (BrC) aerosols in northwest China, Atmos. Chem. Phys., 20, 4889-4904, https://doi.org/10.5194/acp-20-4889-2020, 2020b.

Lin, M. and Yu, J. Z.: Dithiothreitol (DTT) concentration effect and its implications on the applicability of DTT assay to evaluate the oxidative potential of atmospheric aerosol samples, Environ. Pollut., 251, 938-944, https://doi.org/10.1016/j.envpol.2019.05.074, 2019.
Lin, P. and Yu, J. Z.: Generation of reactive oxygen species mediated by humic-like substances in atmospheric aerosols, Environ. Sci. Technol., 45, 10362-10368, https://doi.org/10.1021/es2028229, 2011.

Lin, P., Laskin, J., Nizkorodov, S. A., and Laskin, A.: Revealing Brown Carbon Chromophores Produced in Reactions of Methylglyoxal with Ammonium Sulfate, Environ. Sci. Technol., 49, 14257-14266, https://doi.org/10.1021/acs.est.5b03608, 2015.

Lin, P., Aiona, P. K., Li, Y., Shiraiwa, M., Laskin, J., Nizkorodov, S. A., and Laskin, A.: Molecular Characterization of Brown Carbon in Biomass Burning Aerosol Particles, Environ. Sci. Technol., 50, 11815-11824, https://doi.org/10.1021/acs.est.6b03024, 2016.

Ma, Y., Cheng, Y., Qiu, X., Cao, G., Fang, Y., Wang, J., Zhu, T., $\mathrm{Yu}, \mathrm{J}$., and $\mathrm{Hu}, \mathrm{D} .:$ Sources and oxidative potential of watersoluble humic-like substances (HULIS ${ }_{\mathrm{WS}}$ ) in fine particulate matter $\left(\mathrm{PM}_{2.5}\right)$ in Beijing, Atmos. Chem. Phys., 18, 5607-5617, https://doi.org/10.5194/acp-18-5607-2018, 2018.

Matos, J. T. V., Freire, S. M. S. C., Duarte, R. M. B. O., and Duarte, A. C.: Natural organic matter in urban aerosols: Comparison between water and alkaline soluble components using excitation-emission matrix fluorescence spectroscopy and multiway data analysis, Atmos. Environ., 102, 1-10, https://doi.org/10.1016/j.atmosenv.2014.11.042, 2015.

Mostofa, K. M. G., Wu, F. C., Liu, C. Q., Vione, D., Yoshioka, T., Sakugawa, H., and Tanoue, E.: Photochemical, microbial and metal complexation behavior of fluorescent dissolved organic matter in the aquatic environments, Geochem. J., 45, 235-254, 2011.

Moufarrej, L., Courcot, D., and Ledoux, F.: Assessment of the $\mathrm{PM}_{2.5}$ oxidative potential in a coastal industrial city in Northern France: Relationships with chemical composition, local emissions and long range sources, Sci. Total Environ., 748, 141448, 10.1016/j.scitotenv.2020.141448, 2020.

Mukherjee, A., Dey, S., Rana, A., Jia, S., Banerjee, S., and Sarkar, S.: Sources and atmospheric processing of brown carbon and HULIS in the Indo-Gangetic Plain: Insights from compositional analysis, Environ. Pollut., 267, 115440, https://doi.org/10.1016/j.envpol.2020.115440, 2020.

Murphy, K. R., Butler, K. D., Spencer, R. G. M., Stedmon, C. A., Boehme, J. R., and Aiken, G. R.: Measurement of Dissolved Organic Matter Fluorescence in Aquatic Environments: An Interlaboratory Comparison, Environ. Sci. Technol., 44, 9405-9412, https://doi.org/10.1021/es102362t, 2010.

Murphy, K. R., Hambly, A., Singh, S., Henderson, R. K., Baker, A., Stuetz, R., and Khan, S. J.: Organic matter fluorescence in municipal water recycling schemes: toward a unified PARAFAC model, Environ. Sci. Technol., 45, 2909-2916, https://doi.org/10.1021/es103015e, 2011.

Murphy, K. R., Stedmon, C. A., Graeber, D., and Bro, R.: Fluorescence spectroscopy and multi-way techniques. PARAFAC, Anal. Meth., 5, 6557, https://doi.org/10.1039/c3ay41160e, 2013.

Nozière, B., González, N. J. D., Borg-Karlson, A.-K., Pei, Y., Redeby, J. P., Krejci, R., Dommen, J., Prevot, A. S. H., and Anthonsen, T.: Atmospheric chemistry in stereo: A new look at secondary organic aerosols from isoprene, Geophys. Res. Lett., 38, L11807, https://doi.org/10.1029/2011g1047323, 2011.

Paglione, M., Saarikoski, S., Carbone, S., Hillamo, R., Facchini, M. C., Finessi, E., Giulianelli, L., Carbone, C., Fuzzi, S., Moretti, F., 
Tagliavini, E., Swietlicki, E., Eriksson Stenström, K., Prévôt, A. S. H., Massoli, P., Canaragatna, M., Worsnop, D., and Decesari, S.: Primary and secondary biomass burning aerosols determined by proton nuclear magnetic resonance $\left({ }^{1} \mathrm{H}-\mathrm{NMR}\right)$ spectroscopy during the 2008 EUCAARI campaign in the Po Valley (Italy), Atmos. Chem. Phys., 14, 5089-5110, https://doi.org/10.5194/acp14-5089-2014, 2014.

Park, S.-S. and Yu, J.: Chemical and light absorption properties of humic-like substances from biomass burning emissions under controlled combustion experiments, Atmos. Environ., 136, 114122, https://doi.org/10.1016/j.atmosenv.2016.04.022, 2016.

Park, S.-S., Sim, S. Y., Bae, M.-S., and Schauer, J. J.: Size distribution of water-soluble components in particulate matter emitted from biomass burning, Atmos. Environ., 73, 62-72, https://doi.org/10.1016/j.atmosenv.2013.03.025, 2013.

Pietrogrande, M. C., Bertoli, I., Clauser, G., Dalpiaz, C., Dell'Anna, R., Lazzeri, P., Lenzi, W., and Russo, M.: Chemical composition and oxidative potential of atmospheric particles heavily impacted by residential wood burning in the alpine region of northern Italy, Atmos. Environ., 253, 118360, https://doi.org/10.1016/j.atmosenv.2021.118360, 2021.

Qin, J., Zhang, L., Zhou, X., Duan, J., Mu, S., Xiao, K., Hu, J., and Tan, J.: Fluorescence fingerprinting properties for exploring water-soluble organic compounds in $\mathrm{PM}_{2.5}$ in an industrial city of northwest China, Atmos. Environ., 184, 203-211, https://doi.org/10.1016/j.atmosenv.2018.04.049, 2018.

Sannigrahi, P., Sullivan, A. P., Weber, R. J., and Ingall, E. D.: Characterization of water-soluble organic carbon in urban atmospheric aerosols using solid-state C-13 NMR spectroscopy, Environ. Sci. Technol., 40, 666-672, https://doi.org/10.1021/es051150i, 2006.

Santos, P. S., Otero, M., Duarte, R. M., and Duarte, A. C.: Spectroscopic characterization of dissolved organic matter isolated from rainwater, Chemosphere, 74, 1053-1061, https://doi.org/10.1016/j.chemosphere.2008.10.061, 2009.

Santos, P. S., Santos, E. B., and Duarte, A. C.: First spectroscopic study on the structural features of dissolved organic matter isolated from rainwater in different seasons, Sci. Total Environ., 426, 172-179, https://doi.org/10.1016/j.scitotenv.2012.03.023, 2012.

Seo, I., Lee, K., Bae, M. S., Park, M., Maskey, S., Seo, A., Borlaza, L. J. S., Cosep, E. M. R., and Park, K.: Comparison of physical and chemical characteristics and oxidative potential of fine particles emitted from rice straw and pine stem burning, Environ. Pollut., 267, 115599, https://doi.org/10.1016/j.envpol.2020.115599, 2020.

Shen, G., Chen, Y., Wei, S., Fu, X., Zhu, Y., and Tao, S.: Mass absorption efficiency of elemental carbon for source samples from residential biomass and coal combustions, Atmos. Environ., 79, 79-84, https://doi.org/10.1016/j.atmosenv.2013.05.082, 2013.

Singh, G. K., Choudhary, V., Rajeev, P., Paul, D., and Gupta, T.: Understanding the origin of carbonaceous aerosols during periods of extensive biomass burning in northern India, Environ. Pollut., 270, 116082, https://doi.org/10.1016/j.envpol.2020.116082, 2021.

Sun, J., Zhi, G., Hitzenberger, R., Chen, Y., Tian, C., Zhang, Y., Feng, Y., Cheng, M., Zhang, Y., Cai, J., Chen, F., Qiu, Y., Jiang, Z., Li, J., Zhang, G., and Mo, Y.: Emission factors and light absorption properties of brown carbon from household coal combustion in China, Atmos. Chem. Phys., 17, 4769-4780, https://doi.org/10.5194/acp-17-4769-2017, 2017.

van der Werf, G. R., Randerson, J. T., Giglio, L., Collatz, G. J., Mu, M., Kasibhatla, P. S., Morton, D. C., DeFries, R. S., Jin, Y., and van Leeuwen, T. T.: Global fire emissions and the contribution of deforestation, savanna, forest, agricultural, and peat fires (1997-2009), Atmos. Chem. Phys., 10, 11707-11735, https://doi.org/10.5194/acp-10-11707-2010, 2010.

Verma, V., Rico-Martinez, R., Kotra, N., King, L., Liu, J., Snell, T. W., and Weber, R. J.: Contribution of water-soluble and insoluble components and their hydrophobic/hydrophilic subfractions to the reactive oxygen species-generating potential of fine ambient aerosols, Environ. Sci. Technol., 46, 11384-11392, https://doi.org/10.1021/es302484r, 2012.

Verma, V., Fang, T., Guo, H., King, L., Bates, J. T., Peltier, R. E., Edgerton, E., Russell, A. G., and Weber, R. J.: Reactive oxygen species associated with water-soluble $\mathrm{PM}_{2.5}$ in the southeastern United States: spatiotemporal trends and source apportionment, Atmos. Chem. Phys., 14, 12915-12930, https://doi.org/10.5194/acp-14-12915-2014, 2014.

Verma, V., Wang, Y., El-Afifi, R., Fang, T., Rowland, J., Russell, A. G., and Weber, R. J.: Fractionating ambient humic-like substances (HULIS) for their reactive oxygen species activity - Assessing the importance of quinones and atmospheric aging, Atmos. Environ., 120, 351-359, https://doi.org/10.1016/j.atmosenv.2015.09.010, 2015.

Win, M. S., Tian, Z., Zhao, H., Xiao, K., Peng, J., Shang, Y., Wu, M., Xiu, G., Lu, S., Yonemochi, S., and Wang, Q.: Atmospheric HULIS and its ability to mediate the reactive oxygen species (ROS): A review, J. Environ. Sci., 71, 13-31, https://doi.org/10.1016/j.jes.2017.12.004, 2018.

Wong, J. P. S., Tsagkaraki, M., Tsiodra, I., Mihalopoulos, N., Violaki, K., Kanakidou, M., Sciare, J., Nenes, A., and Weber, R. J.: Effects of Atmospheric Processing on the Oxidative Potential of Biomass Burning Organic Aerosols, Environ. Sci. Technol., 53, 6747-6756, https://doi.org/10.1021/acs.est.9b01034, 2019.

Wu, D., Wang, Z., Chen, J., Kong, S., Fu, X., Deng, H., Shao, G., and Wu, G.: Polycyclic aromatic hydrocarbons (PAHs) in atmospheric $\mathrm{PM}_{2.5}$ and $\mathrm{PM}_{10}$ at a coal-based industrial city: Implication for PAH control at industrial agglomeration regions, China, Atmos. Res., 149, 217-229, https://doi.org/10.1016/j.atmosres.2014.06.012, 2014.

Wu, G., Wan, X., Ram, K., Li, P., Liu, B., Yin, Y., Fu, P., Loewen, M., Gao, S., Kang, S., Kawamura, K., Wang, Y., and Cong, Z.: Light absorption, fluorescence properties and sources of brown carbon aerosols in the Southeast Tibetan Plateau, Environ. Pollut., 257, 113616, https://doi.org/10.1016/j.envpol.2019.113616, 2020.

Wu, X., Liu, W., Gao, H., Alfaro, D., Sun, S., Lei, R., Jia, T., and Zheng, M.: Coordinated effects of air pollution control devices on PAH emissions in coal-fired power plants and industrial boilers, Sci. Total Environ., 756, 144063, https://doi.org/10.1016/j.scitotenv.2020.144063, 2021.

Yan, C., Zheng, M., Sullivan, A. P., Bosch, C., Desyaterik, Y., Andersson, A., Li, X., Guo, X., Zhou, T., Gustafsson, Ö., and Collett, J. L.: Chemical characteristics and lightabsorbing property of water-soluble organic carbon in Beijing: Biomass burning contributions, Atmos. Environ., 121, 4-12, https://doi.org/10.1016/j.atmosenv.2015.05.005, 2015. 
Yu, S., Liu, W., Xu, Y., Yi, K., Zhou, M., Tao, S., and Liu, W.: Characteristics and oxidative potential of atmospheric $\mathrm{PM}_{2.5}$ in Beijing: Source apportionment and seasonal variation, Sci. Total Environ., 650, 277-287, https://doi.org/10.1016/j.scitotenv.2018.09.021, 2019.

Zhang, X., Lin, Y. H., Surratt, J. D., and Weber, R. J.: Sources, composition and absorption Angstrom exponent of light-absorbing organic components in aerosol extracts from the Los Angeles Basin, Environ. Sci. Technol., 47, 3685-3693, https://doi.org/10.1021/es305047b, 2013.
Zhu, J., Chen, Y., Shang, J., and Zhu, T.: Effects of air/fuel ratio and ozone aging on physicochemical properties and oxidative potential of soot particles, Chemosphere, 220, 883-891, https://doi.org/10.1016/j.chemosphere.2018.12.107, 2019.

Zou, C., Li, M., Cao, T., Zhu, M., Fan, X., Peng, S., Song, J., Jiang, B., Jia, W., Yu, C., Song, H., Yu, Z., Li, J., Zhang, G., and Peng, P. A.: Comparison of solid phase extraction methods for the measurement of humic-like substances (HULIS) in atmospheric particles, Atmos. Environ., 225, 117370, https://doi.org/10.1016/j.atmosenv.2020.117370, 2020. 